\title{
Price analysis between commodity groups of inflation in Banten province from 2008 to 2018
}

Deswita Herlina $^{*}$, Amalia Romadhona ${ }^{2}$

Fakultas Ekonomi dan Bisnis, Universitas Sultan Ageng Tirtayasa ${ }^{1,2}$

deswita@untirta.ac.id ${ }^{1 *}$, amalia.romadhona@untirta.ac.id ${ }^{2}$

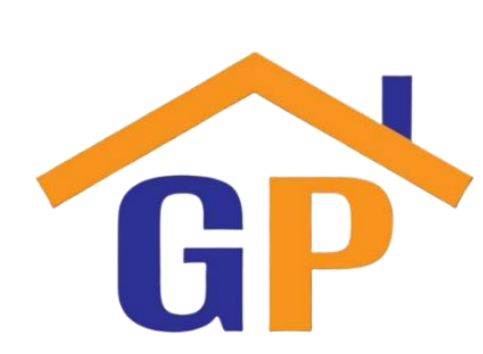

Article History

Received on 14 September 2020

Revised on 13 November 2020

Accepted on 23 February 2021

\begin{abstract}
Purpose: This study aimed to see how each commodity group's movement pattern that forms inflation between one commodity group and another, and to see any major linkages between groups of inflation-forming commodities in Banten Province.
\end{abstract}

Research methodology: The research is undergone by using the Vector Auto Regressive (VAR) model approach through testing of Impulse Response Function (IRF) and Variance Decomposition (VD).

Results: The results show that the inflation rate in the goods/services commodity groups in Banten Province have a dynamic relationship between one another. The group itself dominates inflationary movements in all commodity groups. Monthly time series data is used for 2008-2018 time spans.

Limitation: The linkages presented as the results are performed in commodity groups; thus, further research would inform more about inter-linkage between commodities.

Contribution: The insight of knowing the pattern is beneficial for implication policy in regional inflation targeting especially in Banten Province.

Keywords: Inflation, IRF, VAR, VD

How to cite: Herlina, D., \& Romadhona, A. (2021). Price analysis between commodity groups of inflation in Banten province from 2008 to 2018. International Journal of Financial, Accounting, and Management, 2(4), 321-341.

\section{Introduction}

The macroeconomic stability of a country can be seen from the country's ability to control inflation. The short definition of inflation is the tendency for prices to increase in general and continuously over some time (Mankiw, 2019). The inflation rate in Indonesia can be seen through the Consumer Price Index (CPI). CPI value indicates the change in the average price paid by consumers of a particular group of goods or services. Based on the 2012 Cost of Living Survey (SBH) by BPS, the calculation of consumer goods or services CPI is grouped into seven expense groups. The seven spending groups include; groceries; processed food, beverages, cigarettes, tobacco; housing, water, electricity, gas, fuel; clothes; health; education, recreation, and sports; transportation, communications, and financial services.

This study was conducted to determine how the movement patterns of each group of inflation-forming commodities between one commodity group and another group of commodities. However, the price of a commodity in an economy is certainly influenced by other commodity prices. In the production process of a commodity, the pricing pattern is influenced by the inputs that play a role in the output production process. Thus, this study tries to see how much linkage between the inflation-forming commodity groups in Banten Province. In this study, we wanted to see how the price of each group of inflation-forming commodities moved randomly and acted as endogenous variables that opened up the effect of price formation by price on other commodity groups. Clements \& Izan (1987) in Azwar (2016) estimated the consumer price index's commodity shaper simultaneously to see how the movement patterns and associations are. Thus, departing from the result, it can be seen how the 
economic phenomenon that occurs behind the pattern of interconnectedness between prices on the sharing of commodity groups in shaping inflation.

Inflation is not only happening at the national level, but so does at the regional level. Wimanda (2006) in Azwar (2016) in his study suggested that after the economic crisis the rate of inflation volatility in the region became higher. In addition, regional inflation and national inflation do not indicate the convergence, so the movement pattern is often different from national inflation. This condition may result in monetary policy implementation is not fully effective in suppressing the regional inflation rate. This was supported by Carlino \& Defina (1998) in Azwar (2016) who mentioned that theoretically monetary policy is a national policy. The calculation of inflation nationally is the result of a compilation of inflation calculations throughout the region that have been weighted. Inflation in Banten Province is represented by Serang City, Cilegon City and Tangerang City, as CPI city in Banten Province. The inflation weight of these cities is different from each other, where Serang City has an inflation weight of 14.98 percent against Banten Province's inflation based on survey of living cost at 2012. Meanwhile, the inflation weight of Cilegon city and Tangerang city to Banten Province is 13.11 and 71.91 percent.

Data from Statistics Office (BPS) shows that inflation in Banten Province according to Boediono (2014) is in the category of mild inflation (below 10\%). This can be a stimulant to drive the economy of Banten. The high economic activity can be achieved by controlling the rate of inflation. However, there is a trade-off where the increase in output growth (decrease in the unemployment rate) tends to be followed by the rising inflation rate. The Phillipis Curve indicates the tradeoff between the unemployment rate and the inflation rate. This condition is indicated by empirical data that occurred in Banten. Although Banten's inflation rate is still low, the open unemployment rate (TPT) was placed first among other provinces in 2018 at $7.77 \%$ while the national TPT figure was only $5.13 \%$. At the same time, Banten's economic growth rate reached $5.82 \%$. There is a negative relationship between the unemployment rate and economic growth in Banten Province in accordance with Okun Law (Darman, 2013). Therefore, inflation control in Banten Province is key to addressing employment and welfare issues. In line with this, the government has been working to provide jobs through the large number of Banten Province industries with an industry growth rate in 2017 of $20.87 \%$.

When conducting an analysis on regional inflation control, it is insufficient for focussing only on certain commodity groups that are considered the biggest contributors to regional inflation. Other commodity groups also contribute to the formation of regional inflation. There has been some research on the interconnectedness between commodity groups. The results of Ramadhan (2007) in Bima's (2017) study mentioned that the group of processed food commodities, beverages, cigarettes, and tobacco is influenced by food groups, as well as transportation, communication, and financial services. In addition, most of all commodity groups are also affected by the movement of commodity materials themselves. Hartanto (2011) in Bima (2017) examined the price relationship between inflation-forming commodity groups in Indonesia from 2004 to 2010. The results of the impluse response show several commodity groups contribute in determining the price of other commodities.

The interconnectivity of the goods/services commodity group is one of the factors that shape inflation. Inflationary inter-output can occur due to contagion effect. Contagion is broadly defined as the transmission of shocks between commodity groups of goods/services. Shock can be transmitted qualitatively in two ways: the association between commodity groups of goods/services stable (channels) and sudden changes (shifts) in the interconnectedness of fickle persistence. The shock can be negative shocks and also positive spill-over effects. Contagion effect can also be interpreted as propagation of shocks between two or more commodity groups of goods/services. From that definition, the contagion effect between the inflation of the goods/services commodity group can occur because the price shock that occurs in a commodity can be caused by the shock that occurs in other commodity groups. This research discusses the inter-commodity price relationship in inflation in Banten Province. The reason why this study is focused on a regional scale, is that each region has different characteristics especially when associated with commodities that make up regional inflation, so inflation control policies differ in each region. 


\section{Literature review and hypothesis development}

\subsection{Theory of inflation}

Inflation is a phenomenon found in almost all countries of the world. Practically the definition of inflation is the general trend of rising prices - the price of goods and services simultaneously and continuously (Mankiw, 2019: 145). These prices do not mean to rise with the same percentage. Even if they occur not simultaneously in an instantaneous tempo, the price increase that occurs is continuous for a certain period. If the price increase occurs only once even in a considerable jump, then inflation cannot be said. The inflation rate is used to describe changes in prices that apply from one period to another. To determine it is necessary to pay attention to consumer price index data from one particular period onwards than the previous period's price index. The formula used to determine inflation rate is as follows (Suharyadi \& Purwanto, 2013).

$$
\Pi=\text { x 100(IHKt-IHKt-1)/(IHKt-1) }
$$

Description:

$$
\begin{aligned}
& \Pi \quad \text { : Inflation Rate, } \\
& \text { CPI : Period-to-period consumer price index, } \\
& \text { IHKt-1 : Consumer price index period to t-1 (last period). }
\end{aligned}
$$

The classic theory of inflation that is still relevant to explain the process of inflation in the current era is the quantity theory (Boediono, 2014). Inflation can only occur if there is an increase in circulation volume, without any increase in the amount of money in circulation. The rate of inflation is determined by the rate of increase in the amount of money in circulation and the community's psychology (expectations) regarding future prices. According to Keynes Theory, inflation occurs due to a society that wants to live outside the limits of its economic capabilities (Boediono, 2014). The process of inflation, in this view, is nothing but a process of grabbing the share of wealth among social groups who want a greater share than those communities can provide. This seizure process eventually translates into a situation where the public demand for goods always exceeds the number of goods available (the onset of the so-called inflationary gap).).

The inflationary gap arises because the community manages to translate their aspirations into an effective demand for goods. In other words, they managed to raise funds to turn their aspirations into a plan to purchase funds-backed goods. This kind of society may be the government itself, which seeks to gain a greater share of people's output by running deficits in its budget financed by printing new money. The group may also be private entrepreneurs who want new investments and obtain their financing funds from banks' credit. Trade unions are trying to get a raise for their members beyond the increase in labor productivity. This theory can be called the long-term inflation theory, which is when inflation is associated with the economy's structural factors (Boediono, 2014). There are three things to note, namely as follows. This theory describes the long-term inflation process in developing countries, which is based on experience in Latin American countries. The pressure is on the rigidity of the economic structure of developing countries. This theory is also called the long-term inflation theory because it accompanies the causes of inflation derived from the economic structure's strength. According to this theory, there is a rigidity in developing countries' economies that can cause inflation, among others.

The rigidity of export receipts, namely the sluggish value of exports, is compared to other sectors' growth. This rigidity is due to prices in the world market of the country's exported goods being less profitable and the supply or production of exported goods that are not responsive to rising prices. As a result, the country was forced to take development policies that emphasized the reduction of domestic production of previously imported goods, although often domestic production has higher production costs with lower quality resulting in higher prices and this is what causes inflation. The rigidity of food production from within the country, where domestic grocery production does not grow as fast as population growth and per capita income, so the prices of groceries in the country tend to rise beyond other goods' price increase. As a result, there is a demand from employees to earn salaries resulting in an increase in production costs, which also means an increase in the price of goods, ultimately leading to inflation. There is an assumption that the amount of money in circulation increases and passively follows and accommodates the price increase - the price. In other words, the inflation process can 
continue only if the amount of money in circulation also increases steadily. Without an increase in the amount of money, the process will stop by itself. Structural factors are said to be the most fundamental reason for the inflation process is not $100 \%$ structural. It is often found that this information is due to the government's own price or monetary policy.

\subsection{The relationship between commodity prices and inflation formation}

The prices of each inflation-forming commodity group move randomly and act as endogenous variables that unlock the effect of price formation by price on other commodity groups. As in Clements and Izan (1987) in Azwar (2016) estimated the commodity shaper of the consumer price index simultaneously to see how the movement patterns and associations are. Thus, departing from the result, it can be seen how the economic phenomenon that occurs behind the pattern of interconnectedness between prices in various commodity groups is shaping inflation.

As well as Stock and Watson (2005) in Azwar (2016), it also uses price data of consumer price indexforming goods groups to enrich the dynamic analysis of interconnectedness between economic variables. Using vector auto-regression (VAR), Stock and Watson models include a number of these time series to see the interconnectedness between these commodity groups and some other macroeconomic variables. Wimanda (2006) in Azwar (2016) in his study on regional inflation in Indonesia suggested that after the economic crisis the level of inflation volatility in the region became higher. Inflation in the transportation group contributes greatly to the shaper of inflation in the region; it is also inseparable from the influence of fuel prices. Then, the increase in prices in the commodity group impacts inflation in the food, processed food, and housing groups. In addition, regional inflation and national inflation do not indicate convergence, so the movement pattern is often different from the national inflation movement. This can result in monetary policy not being fully effective in suppressing the rate of inflation in the region. As in Carlino and Defina (1998) in Azwar (2016), it states that theoretically, monetary policy is a national-scale policy. However, in reality, there is a regional divergence in response to these economic aggregate variables' shocks.

The development of prices determined by the government (administered prices) as well as fuel oil (BBM), certainly has its own impact on prices in the transportation sector. This will then impact other commodities that use fuel oil in the production and distribution process. As in Madjardi (2002) in Azwar (2016), the development of fuel prices, which is one of the components of administered prices, is often the main cause of the high development of administered goods prices and CPI inflation development in general. In terms of agricultural commodity products, of course, many factors influence the pricing, ranging from season factors, weather, to smooth distribution and supply lines. The price shock in this commodity that is included in the grocery group will be directly felt in other commodity groups that use agricultural commodity products or food groups as raw materials.

\section{Research methodology}

\subsection{Research data and variables}

The data used were secondary data time series, the monthly period of 2008:1 to 2018: 12. Data sources were obtained through official government agencies such as the Central Bureau of Statistics (BPS) years edition, The Economic and Financial Statistics of Indonesia (SEKI) issued by Bank Indonesia, and the Annual Report of Bank Indonesia. The study discussed 7 variables, namely variable inflation-forming commodity groups consisting of food group groups (BAMA); processed food groups, beverages, cigarettes and tobacco (MAJAMIROTE); housing, water, electricity, gas and fuel groups (PALIGABA); sandang group (SAND); health groups (KES); education, recreation and sports groups (PENDIREKOR); transportation, communication and financial services (TRASKOJA).

\subsection{Analysis method}

The data analysis techniques used for data processing in this study were Vector Autoregressive (VAR) models or vecm models. Prior to var or VECM estimation, testing of research data was conducted. The tests were data stationerity test and co-integration test then followed by optimal lag determination, impulse response function (IRF), decomposition variant (VariantDecomposition). To analyze the data, VAR or VECM method is done; the first step is testing data stationerity. Data 
stationarity testing is critical in determining the exact analysis tools of whether VAR or VECM. Data that has a stationer at the level can be used var analysis at the level. However, if the data is not stationer at the level but at the first degree used var analysis tool at the first level (1'st), there is no data co-integration. In the event of data co-integration, vector error correction model (VECM) estimation was carried out.

\subsection{Data stationarity test}

The VAR model requires a data stationarity test. A data is said to be stationary if its average values, variances, and covariance are always constant and independent of time (Gujarati \& Porter, 2013). The presence of non-stationary variables increases the likelihood of co-integration relationships between variables, where the coefficient value resulting from the regression result will be invalid due to a biased standard error. Therefore, the root test unit needs to be performed to test whether there is a root unit in the data series used or not. To find out, stationary tests were conducted using the Augmented Dickey Fuller (ADF) test or the Phillips-Perron (PP) method. In this study the data stationary used was a stationary test or unit root test with Dickey-Fuller test (DF) and Augmented Dickey Fuller (ADF).

In accordance with this study's purpose to find out how prices are related to the inflation-forming commodity group, this study will be designed using a VAR model that assumes all variables in the model are endogenous and estimated simultaneously (Gujarati \& Porter, 2013). Var model estimates include endogenous variables that were influenced by the variables themselves in the previous period (lagged or past value) and the influence of other endogenous variables in the model. In addition, before making such estimates, it must also be ensured that the equations in the system are identified either exactly-identified or over-identified.

The equations in the system on this VAR model are as follows:

BAMAt $=\mathrm{C}_{1}+\mathrm{a}_{1 \mathrm{i}} \sum_{\text {BAMA }}$ BAM $_{\mathrm{t}-\mathrm{k}}+\mathrm{a}_{1 \mathrm{i}} \sum$ MMAJAMIROTE $_{\mathrm{t}-\mathrm{k}}+\mathrm{a}_{1 \mathrm{i}} \sum$ PALIGAMA $_{\mathrm{t}-\mathrm{k}}+\mathrm{a}_{1 \mathrm{i}}$
$\sum_{\text {ci }}$ SAND $_{\mathrm{t}-\mathrm{k}}+\mathrm{a}_{1 \mathrm{i}} \sum \mathrm{KES}_{\mathrm{t}-\mathrm{k}}+\mathrm{a}_{1 \mathrm{i}} \sum$ PENDIREKOR $_{\mathrm{t}-\mathrm{k}}+\mathrm{a}_{1 \mathrm{i}} \sum$ TRASKOJA $_{\mathrm{t}-\mathrm{k}}+\mathrm{a}_{1 \mathrm{i}} \sum \mathrm{INF}_{\mathrm{t}-\mathrm{k}}+$

MAJAMIROTEt $=\mathrm{C}_{2}+\mathrm{a}_{2 \mathrm{i}} \sum$ BAMA $_{\mathrm{t}-\mathrm{k}}+\mathrm{a}_{2 \mathrm{i}} \sum$ MAJAMIROTE $_{\mathrm{t}-\mathrm{k}}+\mathrm{a}_{2 \mathrm{i}}$ PPALIGAMA $_{\mathrm{t}-\mathrm{k}}+$ $\mathrm{a}_{2 \mathrm{i}} \sum_{\mathrm{SAND}_{\mathrm{t}-\mathrm{k}}}+\mathrm{a}_{2 \mathrm{i}} \sum$ KES $_{\mathrm{t}-\mathrm{k}}+\mathrm{a}_{2 \mathrm{i}} \sum$ PENDIREKOR $_{\mathrm{t}-\mathrm{k}}++\mathrm{a}_{2 \mathrm{i}} \sum_{\text {TRASKOJA }}$ TR-k $+\mathrm{a}_{2 \mathrm{i}}$ $\sum \mathrm{INF}_{\mathrm{t}-\mathrm{k}}+\varepsilon \mathrm{i}$

PALIGAMAt $=\mathrm{C} 3+{ }_{\mathrm{a} 3 \mathrm{i}} \sum \mathrm{BAMA}_{\mathrm{t}-\mathrm{k}}+{ }_{\mathrm{a} 3 \mathrm{i}} \sum$ MAJAMIROTE $_{\mathrm{t}-\mathrm{k}}+{ }_{\mathrm{a} 3 \mathrm{i}} \sum$ PALIGAMA $_{\mathrm{t}-\mathrm{k}}+\mathrm{a}_{3 \mathrm{i}}$

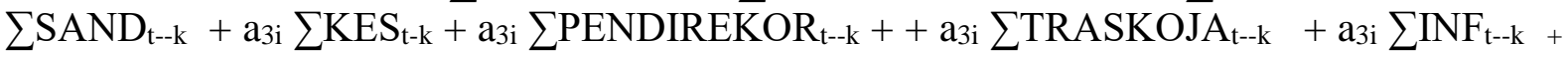
ci

SANDt $=\mathrm{C}_{4}+{ }_{\mathrm{a} 4 \mathrm{i}} \sum$ BAMA $_{\mathrm{t}-\mathrm{k}}+{ }_{\mathrm{a} 4 \mathrm{i}} \sum$ MAJAMIROTE $_{\mathrm{t}-\mathrm{k}}+{ }_{\mathrm{a} 4 \mathrm{i}} \sum$ PALIGAMA $_{\mathrm{t}-\mathrm{k}}+\mathrm{a}_{4 \mathrm{i}}$ $\sum \mathrm{SAND}_{\mathrm{t}-\mathrm{k}}+\mathrm{a}_{4 \mathrm{i}} \sum \mathrm{KES}_{\mathrm{t}-\mathrm{k}}+\mathrm{a}_{4 \mathrm{i}} \sum$ PENDIREKOR $_{\mathrm{t}-\mathrm{k}}++\mathrm{a}_{4 \mathrm{i}} \sum$ TRASKOJA $_{\mathrm{t}-\mathrm{k}}+\mathrm{a}_{4 \mathrm{i}} \sum \mathrm{INF}_{\mathrm{t}-\mathrm{k}}$ $+\varepsilon \mathrm{i}$

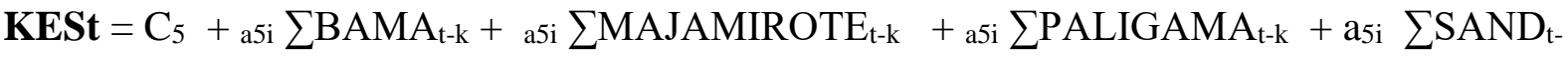
$-\mathrm{k}+\mathrm{a}_{5 \mathrm{i}} \sum \mathrm{KES}_{\mathrm{t}-\mathrm{k}}+\mathrm{a}_{5 \mathrm{i}} \sum$ PENDIREKOR $_{\mathrm{t}-\mathrm{k}}++\mathrm{a}_{5 \mathrm{i}} \sum_{\text {TRASKOJA }}$ TR $\mathrm{k}+\mathrm{a}_{5 \mathrm{i}} \sum \mathrm{INF}_{\mathrm{t}-\mathrm{k}}+\varepsilon \mathrm{i}$

PENDIREKOR $_{\mathbf{t}}=\mathrm{C}_{6}+{ }_{\text {a6i }} \sum$ BAMA $_{\mathrm{t}-\mathrm{k}}+{ }_{\mathrm{a}}$ ai $\sum$ MAJAMIROTE $_{\mathrm{t}-\mathrm{k}}+{ }_{\mathrm{a}} \mathrm{i}_{\mathrm{i}}$ PALIGAMA $_{\mathrm{t}-\mathrm{k}}+$ a 6 i $\sum$ SAND $_{\mathrm{t}-\mathrm{k}}+\mathrm{a}_{6 \mathrm{i}} \sum$ KES $_{\mathrm{t}-\mathrm{k}}+\mathrm{a}_{6 \mathrm{i}} \sum$ PENDIREKOR $_{\mathrm{t}-\mathrm{k}}+\mathrm{a}_{6 \mathrm{i}} \sum$ TRASKOJA $_{\mathrm{t}-\mathrm{k}}+\mathrm{a}_{6 \mathrm{i}} \sum \mathrm{INF}_{\mathrm{t}-\mathrm{k}}$ $+\varepsilon \mathrm{i}$

TRASKOJAt $=\mathrm{C}_{7}+{ }_{\mathrm{a} 7 \mathrm{i}} \sum \mathrm{BAMA}_{\mathrm{t}-\mathrm{k}}+\mathrm{a}_{\mathrm{i}} \sum$ MAJAMIROTE $_{\mathrm{t}-\mathrm{k}}+{ }_{\mathrm{a} 7 \mathrm{i}} \sum$ PALIGAMA $_{\mathrm{t}-\mathrm{k}}+\mathrm{a} 7 \mathrm{i}$ $\sum$ SAND $_{\mathrm{t}-\mathrm{k}}+\mathrm{a}_{7 \mathrm{i}} \sum$ KES $_{\mathrm{t}-\mathrm{k}}+\mathrm{a}_{7 \mathrm{i}} \sum$ PENDIREKOR $_{\mathrm{t}-\mathrm{k}}+\mathrm{a}_{7 \mathrm{i}} \sum$ TRASKOJA $_{\mathrm{t}-\mathrm{k}}+\mathrm{a}_{7 \mathrm{i}} \sum \mathrm{INF}_{\mathrm{t}-\mathrm{k}}+\varepsilon \mathrm{e}$

Derives:

$\begin{array}{lll}\text { BAMA } & \text { grocery group } \\ \text { MAJAMIROTE }= & \text { processed food group, beverage, cigarette and tobacco } \\ \text { PALIGAMA }= & \text { housing group, water, electricity, gas and fuel } \\ \text { SAND } & = & \text { sandang group } \\ \text { KES } & = & \text { health group } \\ \text { PENDIREKOR }= & \text { education, recreation and sports group }\end{array}$




$\begin{array}{lll}\text { TRASKOJA } & = & \text { group transportation, communication and financial services } \\ \varepsilon \mathrm{i} & = & \text { stochastic error term or impulse or innovation or shock in VAR } \\ \mathrm{k} & = & \text { optimal inaction } \\ \mathrm{t} & = & \text { time }\end{array}$

\section{Impulse Response Function (IRF)}

Response to innovation is one of the accessories in VAR used to look at the response of endogenous variables to the influence of shock innovation) other endogenous variables (Pindycks and Rubinfeld; 1998) in Ichsandimas \& Cahyadin (2014). Innovation is interpreted as "policy shock", in Bernanke and Blinder (1992) in Ichsandimas \& Cahyadin (2014). or also often called action. Statically the response to the action is formulated in the Sims equation (1980) in Ichsandimas \& Cahyadin (2014)..

\section{Variance Decomposition (VD)}

Variance decomposition is another method of looking at system dynamics. The impulse response function is used to determine the effect of shock of an endogenous variable against the var. While in variance decomposition describes (decompose) variations of an endogenous variable into the shock component of endogenous variables in VAR. Variance decomposition provides information on the relative importance of each random innovation of variables in VAR.

\section{Results and discussions}

\subsection{Overview of inflation in Banten province}

The contributing factor to Banten's high economic performance in 2018 is the strength of various components of domestic demand in terms of demand. In this case, it means increased household consumption and the uptake of government spending, as well as rising private investment. In addition, the foreign and national demand component also increased. What's more, overseas imports at the same time are increasing, but with a smaller amount of rising imports. Consequently, the trade balance increased so that Banten's economy enjoyed accelerated or accelerated growth. The calculation of inflation nationally results from a compilation of inflation calculations throughout the region that have been weighted. The development of goods and services prices (inflation/deflation) as measured by changes in the Consumer Price Index (CPI) shows that in Banten Province during 2018 there was a lower inflation of $3.42 \%$ (yoy) percent when compared to $3.98 \%$ (yoy) in 2017. Commodity groups that contribute to Banten inflation in a row as follows: grocery group of 0.516 percent, transport, communications and financial services groups by 0.545 percent, processed food, beverage, cigarette and tobacco groups by 0.552 percent, health groups by 0.365 percent, food and beverage groups by 0.190 percent, housing, water, electricity, gas and fuel groups by 0.849 percent while education, recreation and sports groups by 0.397 percent. During 2017 there was higher inflation of 3.98 percent compared to 2016, which was recorded at 2.94 percent. The condition is due to the increase in 900 volt-ampere (VA) electricity tariff at the beginning of the year. However, when looking at inflation in the subgroup of food in 2017 which is only 0.2891 , it is seen that the efforts that have been done by the local government, through the Regional Inflation Control Team (TPID), have been running optimally to maintain the stability of the price of goods and services that Banten people have consumed. This was also the case in 2016 when inflation was 2.94 percent.

In 2015 there was lower inflation of 4.29 percent when compared to 10.20 percent in 2014. Inflation in December was the highest in 2015. Rising prices of onions, red chillies, eggs, and rising chicken meat prices are very significant commodities against the rise in inflation in December 2015. The condition shows that the efforts that the local government has carried out are still processing towards maximum results to maintain the stability of the price of goods and services that have been consumed by the people of Banten. The largest increase in CPI occurred in the health group of 12.78 percent; processed food, beverage, cigarette and tobacco groups 8.18 percent; education, recreation and sports groups 6.05 percent; housing, water, electricity, gas and fuel groups 4.56 percent; food group 3.82 percent; followed later by a 1.90 percent backing group; as well as the last transport, communications and financial services group - 2.20 percent. 


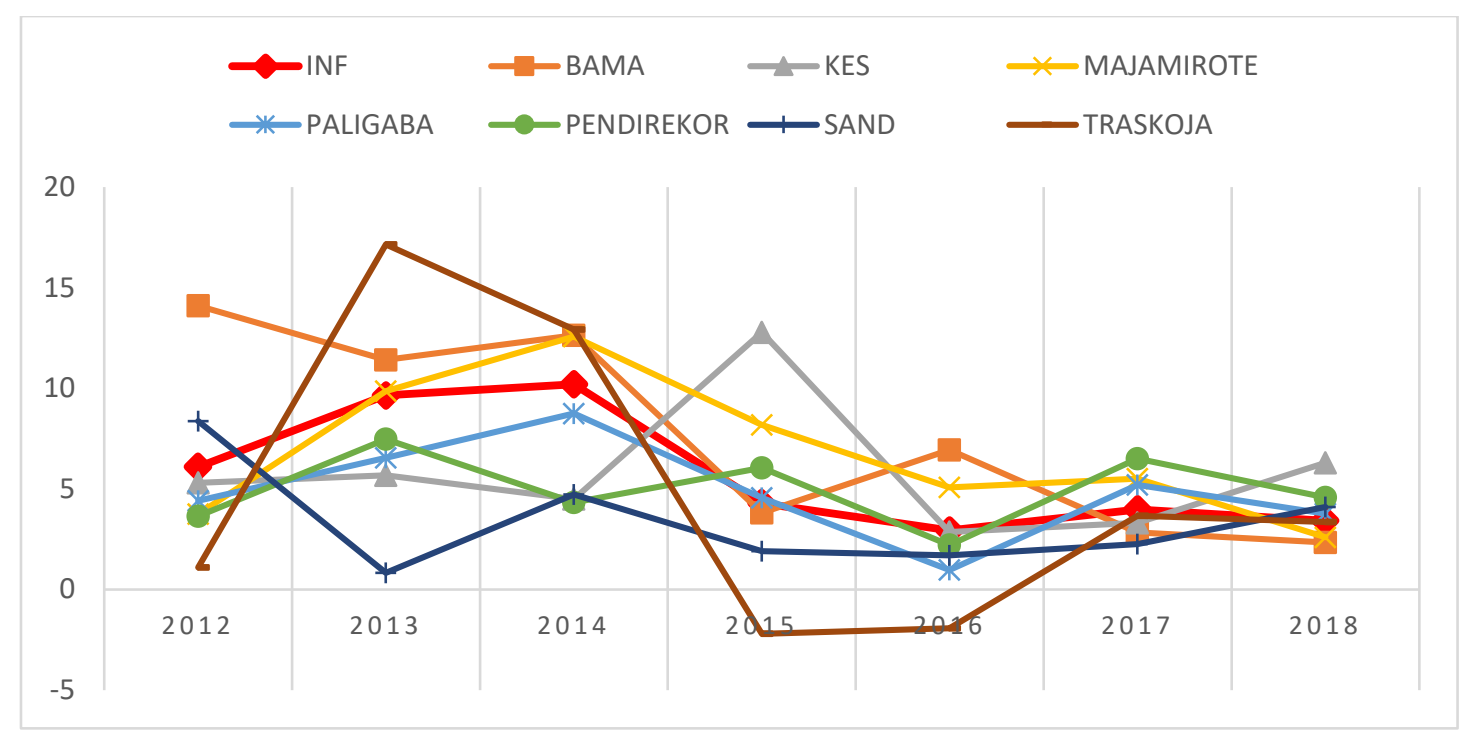

Source: Central Bureau of Statistics, 2020.

Figure 1. Inflation Growth of Banten Province

Inflation remained high at 10.20 percent in 2014 compared to 9.65 percent in 2013. Inflation in December was the highest in 2014. The increase in the price of subsidized fuel oil (BBM) and the surge in chili price is a very significant commodity against the increase in inflation in December 2014. These conditions show that the efforts that the local government has done still do not provide maximum results to maintain the stability of the price of goods and services that have been consumed by the people of Banten. The largest CPI increase occurred in the transport, communications and financial services group of 12.93 percent; followed by the grocery group 12.63 percent; processed food, beverage, cigarette and tobacco groups 12.57 percent; housing, water, electricity, gas and fuel groups 8.75 percent; 4.73 percent; health group 4.49 percent; and last education, recreation and sports groups 4.33 percent.

During 2012 there was a high inflation rate of 6.10 percent compared to 2011, which was only recorded at 2.78 percent. These conditions show that the local government's efforts still do not provide maximum results to maintain the stability of the price of goods and services consumed by the people of Banten. The largest CPI increase occurred in the 14.10 percent grocery group; then the backing group was 8.37 percent; health group 5.30 percent; housing, water, electricity, gas and fuel groups 4.41 percent; processed food groups, beverages, cigarettes and tembajau 3.76 percent; education, recreation and sports groups were 3.64 percent and transport, communication and financial services groups 1.10 percent. Over the past few years, the TRASKOJA group reached the highest inflation rate in 2013 at 17.15 percent, and the lowest level compared to other commodity/service groups reached negative figures in 2015 of -2.2 percent and 2014 of -1.92 percent.

\subsection{Analysis results}

The results of the data analysis in this study are divided into several sections: the results of descriptive statistical analysis, statistical test results before estimation which include data stationary test and optimal lag length, and var model estimation within the framework of Impulse Response Function (IRF) and Variance Decomposition (VD) testing.

\section{Descriptive statistical test results}

The descriptive statistical test results in the following table show that the average inflation rate in MAJAMIROTE group shows the highest average inflation compared to other commodities/service groups, which is 0.60 during the research period. The highest average inflation rate after MAJAMIROTE group was successively followed by BAMA and PENDIREKOR groups with an average inflation value of 0.59 and 0.48 . The average lowest inflation rate during the TRASKOJA 
group's research period was 0.27. Although MAJAMIROTE group has the highest average, the highest point (maximum) inflation is precisely in TRASKOJA group. Within a certain time or month, inflation in Banten has reached the highest point in TRASKOJA group. Another interesting thing is that deflation also occurs in all groups indicated by the minimum point (lowest) during the research period.

Table 1. Descriptive Statistical Test Results

$\begin{array}{cccccc}\begin{array}{c}\text { Inflation } \\ \text { Forming Group }\end{array} & \text { Mean } & \text { Median } & \text { Max. } & \text { Min. } & \begin{array}{c}\text { Standard } \\ \text { Deviation }\end{array} \\ \text { BAMA } & 0,597756 & 0,455000 & 8,860000 & -3,230000 & 1,629056 \\ \text { Who } & 0,472769 & 0,290000 & 5,780000 & -0,280000 & 0,675886 \\ \text { MAJAMIROTE } & 0,605088 & 0,455000 & 3,250066 & -0,020000 & 0,508157 \\ \text { PALIGABA } & 0,401106 & 0,270000 & 3,390674 & -0,760000 & 0,486673 \\ \text { PENDIREKOR } & 0,486025 & 0,150000 & 5,470000 & -0,150000 & 0,949055 \\ \text { SAND } & 0,371491 & 0,260000 & 4,880000 & -2,040000 & 0,739099 \\ \text { TRASKOJA } & 0,279704 & 0,080182 & 10,52000 & -4,830000 & 1,693408\end{array}$

Source: Data processing results, 2020.

\section{Stationary test results}

Based on the unit root test (unit root test) using the ADF test method obtained, all stationary variables at the level with a level of significance of 5\%. The results of the stationary test showed that the data was stationary qualified. Because all variables are stationary at the level level, according to Azwar (2016), the co-integration test does not need to be done. Previously specified models with VAR models can be further estimated.

Table 2. Data stationary test results

\begin{tabular}{ccccc} 
Variable & \multicolumn{2}{c}{ Augmented Dickey-Fuller (ADF) Test } & Test Results \\
& Level & \\
& Critical Values & t-statistic & Prob* $^{*}$ \\
BAMA & $-3,445030$ & $-8,988511$ & 0,0000 & Stationary \\
Who & $-3,444487$ & $-11,40511$ & 0,0000 & Stationary \\
MAJAMIROTE & $-3,444487$ & $-9,336484$ & 0,0000 & Stationary \\
PALIGABA & $-3,444756$ & $-6,288863$ & 0,0000 & Stationary \\
PENDIREKOR & $-3,444487$ & $-10,49596$ & 0,0000 & Stationary \\
SAND & $-3,444487$ & $-10,24407$ & 0,0000 & Stationary \\
TRASKOJA & $-3,444487$ & $-10,28900$ & 0,0000 & Stationary
\end{tabular}

Source: Data processing results, 2020; *) significantly at $\alpha=5 \%$.

\section{VAR Stability test results}

The var model stability test results show that the VAR model used in this study is stable up to lag 8 . This is indicated by a modulus value of less than one. In addition, the stability of the VAR model can also be seen in the absence of points coming out of the circle as shown in the figure 2 . 


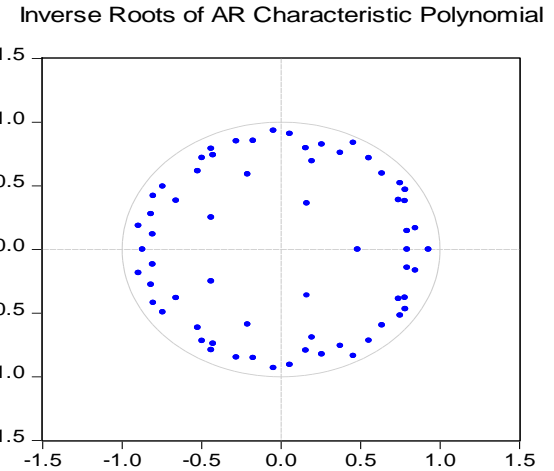

Source: Data processing results, 2020.

Figure 2. VAR Model Stability

\section{Optimum lag length test results}

The lag determination in this study used the Approach of Likelihood Ratio (LR), Final Prediction Error (FPE), Akaike Information Criterion (AIC), Schwarz Information Criterion (SC) and Hannan Quinn (HQ). The results of determining the full lag length can be seen in the table below. Based on the following table according to the criteria of LR, FPE, AIC, SC and HQ whose smallest and most designated values are lag 0 as indicated by the sign $(*)$. However, in the next process to estimate the VAR equation model with IRF and VD devices will be used lag 2 because the VAR model at lag 0 cannot be estimated. Additionally, lag 2 shows the second most asterisk.

Table 3. Optimum lag test results

\begin{tabular}{|ccccccc|}
\hline Lag & LogL & LR & FPE & AIC & SC & HQ \\
& & & & & & \\
0 & -1022.369 & In & $0.038296^{*}$ & $16.60273^{*}$ & $16.76194^{*}$ & $16.66741^{*}$ \\
1 & -985.6972 & 68.61238 & 0.046779 & 16.80157 & 18.07524 & 17.31896 \\
2 & -945.3067 & $71.00909^{*}$ & 0.054130 & 16.94043 & 19.32857 & 17.91055 \\
3 & -905.9633 & 64.72620 & 0.064416 & 17.09618 & 20.59879 & 18.51902 \\
4 & -873.7518 & 49.35627 & 0.087472 & 17.36697 & 21.98404 & 19.24253 \\
5 & -831.0818 & 60.56390 & 0.102721 & 17.46906 & 23.20060 & 19.79735 \\
6 & -786.0023 & 58.89417 & 0.119688 & 17.53230 & 24.37830 & 20.31330 \\
7 & -740.2290 & 54.63266 & 0.143556 & 17.58434 & 25.54481 & 20.81807 \\
8 & -704.8852 & 38.19418 & 0.214511 & 17.80460 & 26.87954 & 21.49105 \\
\hline
\end{tabular}

Source: Data processing results, 2020.

\subsection{Impulse Response Function (IRF) dan Variance Decomposition (VD) \\ IRF Grocery Group (BAMA)}

The IRF's results illustrate that in the first month ahead, if there is a positive shock of one standard deviation (1 S.D.) at the BAMA group price, it will increase the price of the BAMA group itself by $1.54 \%$. However, the impact began to decline from the 2 nd month until it returned to its original price balance in the 3rd month. So, in the event of a shock coming from the BAMA group itself for example due to the influence of weather, season, or crop failure resulting in BAMA supply being choked then there will be an increase in prices that adjustment to the original price quite quickly that is about 3 months.

Table 4. BAMA Group IRF

\begin{tabular}{cccccccc}
\hline \hline Period & BAMA & Who & MAJAMIROTE & PALIGABA & PENDIREKOR & SAND & TRASKOJA \\
\hline \hline 1 & 1.536585 & -0.014134 & 0.021498 & 0.011185 & -0.054440 & 0.114326 \\
2 & 0.347931 & 0.012002 & -0.016735 & 0.094817 & 0.123478 & 0.055920 & 0.164936 \\
3 & 0.037898 & -0.008274 & -0.010131 & 0.023498 & 0.056028 & 0.011197 & 0.052816 \\
4 & -0.003006 & -0.004314 & -0.003591 & 0.002651 & 0.016050 & 0.000297 & 0.011683 \\
5 & -0.003058 & -0.001141 & -0.000976 & -0.000387 & 0.003297 & -0.000510 & 0.002043 \\
6 & -0.001143 & -0.000223 & -0.000245 & -0.000326 & 0.000479 & -0.000209 & $6.69 \mathrm{E}-05$
\end{tabular}




\begin{tabular}{cccccccc}
7 & -0.000362 & $-2.81 \mathrm{E}-05$ & $-5.67 \mathrm{E}-05$ & -0.000128 & $8.79 \mathrm{E}-06$ & $-5.89 \mathrm{E}-05$ & -0.000138 \\
8 & -0.000109 & $1.48 \mathrm{E}-06$ & $-1.12 \mathrm{E}-05$ & $-4.19 \mathrm{E}-05$ & $-3.06 \mathrm{E}-05$ & $-1.44 \mathrm{E}-05$ & $-8.05 \mathrm{E}-05$ \\
9 & $-3.09 \mathrm{E}-05$ & $2.79 \mathrm{E}-06$ & $-1.46 \mathrm{E}-06$ & $-1.25 \mathrm{E}-05$ & $-1.70 \mathrm{E}-05$ & $-3.20 \mathrm{E}-06$ & $-3.24 \mathrm{E}-05$ \\
10 & $-8.05 \mathrm{E}-06$ & $1.37 \mathrm{E}-06$ & $1.50 \mathrm{E}-07$ & $-3.45 \mathrm{E}-06$ & $-6.83 \mathrm{E}-06$ & $-6.21 \mathrm{E}-07$ & $-1.10 \mathrm{E}-05$ \\
\hline \hline
\end{tabular}

Source: Data processing results, 2020.

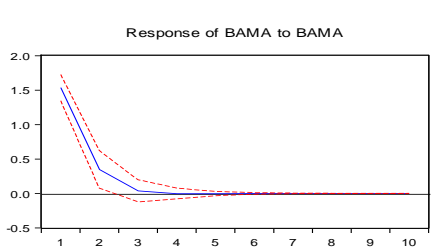

Response of PALIGABA to BAMA

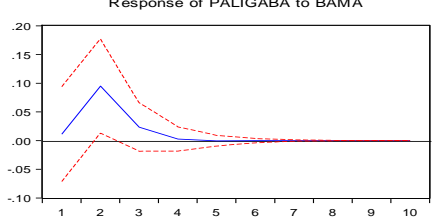

Response of TRASKOJA to BAMA

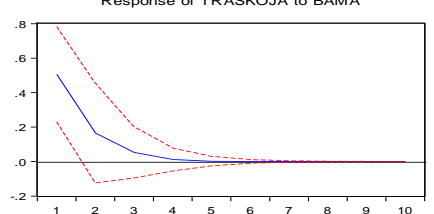

Source: Data processing results, 2020.

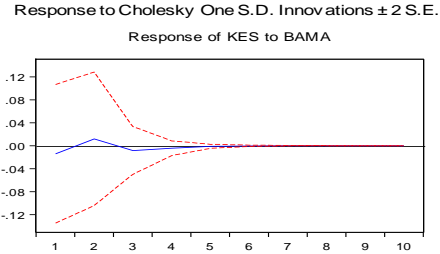

Response of PENDIREKOR to BAMA
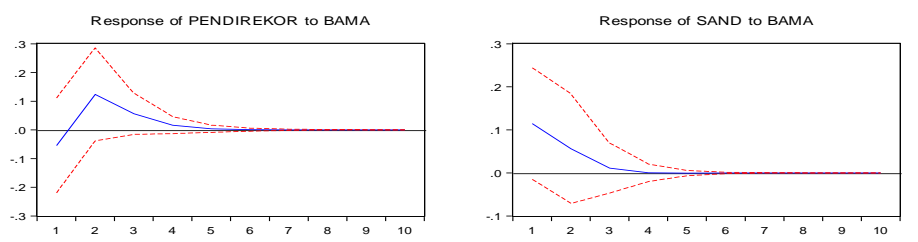

Figure 3. BAMA group IRF

The KES group's shock led to a $-0.01 \%$ drop-in BAMA group prices in the 1st month, which led to an increase in BAMA group prices. In the event of a positive shock of 1 S.D. in MAJAMIROTE group, the price increase of BAMA group in the first month of $0.02 \%$ then there was a continuous decrease in prices until the 9th month, and the price again rose in the 10th month. The shock impact in the 1st month of the PALIGABA group is not very large about $0.01 \%$, including the fuel sub-group. The fuel increase was more responded to by the increase in prices in the BAMA group of TRASKOJA group which included a sub-group of transportation that supported the distribution process, which resulted in an increase in BAMA group prices in the 1st month by $0.51 \%$. But entering the 7 th and 5 th months the impact of the TRASKOJA and SAND groups began to decrease. These results confirm the descriptive analysis in the previous section, in which the price movement of the grocery commodity group was also affected by the shock that occurred in the price of the transport group, related to the increase in fuel prices. PENDIREKOR group also turned out to impact BAMA group by causing price drop in the first month, then from the 2nd to 7th month there was an increase in BAMA group prices. IRF results show that existing shocks (BAMA, PALIGABA, and TRASKOJA) largely began to decline back below the balance price in the 4th-7th month. It can be said that the persistence of price increases in the BAMA group on average lasts 1 to 10 months ahead

\section{IRF Health Group (KES)}

Shock of variable price group KES itself which occurred the highest price increase compared to other groups in the first month, which is $0.69 \%$. PALIGABA group prices also gave shock to the price drop from the 2 nd month to the 7 th month, after which there was a fairly small price increase below $1 \%$. The provision of health services and medical goods production cannot be separated from inputs in PALIGABA groups such as fuel, lighting, and water sub-groups. On average, there was a drop in prices due to the shock of all inflation-forming groups that occurred from the 2 nd month to the 10th month, except the KES group itself and MAJAMIROTE which occurred only in the 2nd and 3rd month. 
Table 5. IRF Group KES

\begin{tabular}{|c|c|c|c|c|c|c|c|}
\hline Period & BAMA & Who & MAJAMIROTE & PALIGABA & PENDIREKOR & SAND & TRASKOJA \\
\hline 1 & 0.000000 & 0.690828 & 0.111319 & 0.014999 & 0.177220 & -0.047267 & 0.024640 \\
\hline 2 & -0.173542 & -0.004789 & -0.011676 & -0.022298 & -0.009181 & 0.062930 & 0.035607 \\
\hline 3 & -0.066929 & -0.010088 & -0.007985 & -0.013372 & 0.001591 & 0.000480 & -0.072543 \\
\hline 4 & -0.019279 & 0.001072 & 0.000572 & -0.006625 & -0.009360 & -0.001810 & -0.015374 \\
\hline 5 & -0.003445 & 0.000663 & 0.000442 & -0.001666 & -0.003854 & -0.000323 & -0.005073 \\
\hline 6 & -0.000401 & 0.000286 & 0.000197 & -0.000309 & -0.001205 & $-5.50 \mathrm{E}-06$ & -0.001377 \\
\hline 7 & $2.60 \mathrm{E}-05$ & $8.77 \mathrm{E}-05$ & $6.87 \mathrm{E}-05$ & $-3.27 \mathrm{E}-05$ & -0.000317 & $2.29 \mathrm{E}-05$ & -0.000317 \\
\hline 8 & 4.09E-05 & $2.22 \mathrm{E}-05$ & $2.10 \mathrm{E}-05$ & $5.80 \mathrm{E}-06$ & $-7.15 \mathrm{E}-05$ & $1.12 \mathrm{E}-05$ & $-5.81 \mathrm{E}-05$ \\
\hline 9 & $1.98 \mathrm{E}-05$ & $4.80 \mathrm{E}-06$ & $5.87 \mathrm{E}-06$ & $5.44 \mathrm{E}-06$ & $-1.30 \mathrm{E}-05$ & $3.90 \mathrm{E}-06$ & $-5.04 \mathrm{E}-06$ \\
\hline 10 & 7.52E-06 & $7.99 \mathrm{E}-07$ & $1.48 \mathrm{E}-06$ & $2.46 \mathrm{E}-06$ & $-1.25 \mathrm{E}-06$ & $1.19 \mathrm{E}-06$ & $2.11 \mathrm{E}-06$ \\
\hline
\end{tabular}

Source: Data processing results, 2020.

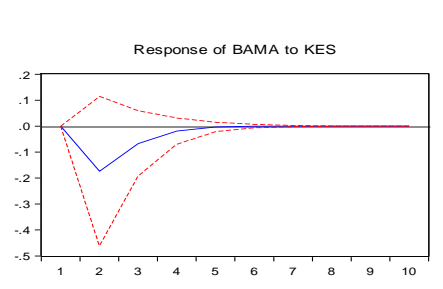

Response of PALIGABA to KES

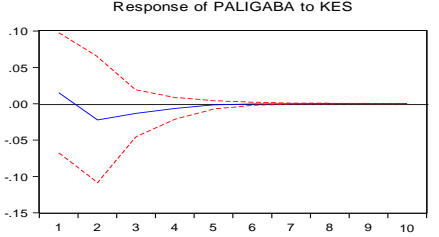

Response of TRASKOJA to KES

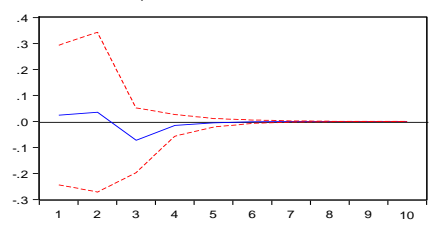

Source: Data processing results, 2020.
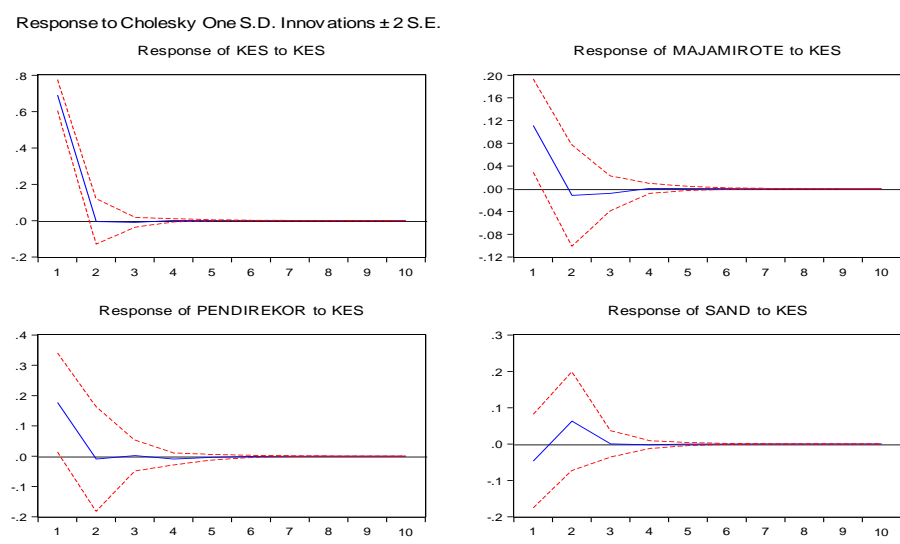

Response of SAND to KES

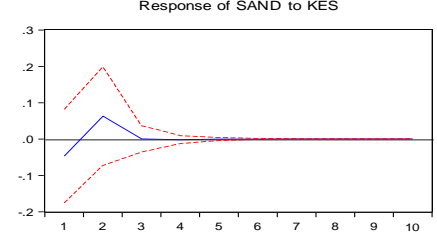

Figure 4. IRF group KES

\section{IRF Group MWill Be So, Beverages, Cigarettes and Tobacco (MAJAMIROTE)}

The IRF results in MAJAMIROTE group show that if there is a positive shock from BAMA and KES group, it will not have any impact on MAJAMIROTE inflation in the first month. The largest price increase occurred when there was shock in MAJAMIROTE group itself by $0.46 \%$ and TRASKOJA group by $0.11 \%$ and there were fluctuations in price increase throughout the period. The BAMA group's shock effect until the 8th month caused fluctuations in price increases in majamiote group and then in the 9th and 10th months experienced a decrease in prices.

The price shock that occurred in PALIGABA group continues to show fluctuations in MAJAMIROTE group price increase until the 9th month with a downward trend. The shock from PALIGABA and TRASKOJA group by 1 S.D. in the first month led to an increase in MAJAMIROTE group prices by $0.06 \%$ and $0.11 \%$. Both groups are widely entered as inputs on MAJAMIROTE group production in addition to raw materials that come from BAMA group. PALIGABA group, which is widely filled by sub-groups of energy and fuel needs, influenced MAJAMIROTE group's increase until the 4th month. After that, it gave the impact of the decrease until the end of the year by $0.0000071 \%$. 
Table 6. MAJAMIROTE Group IRF

\begin{tabular}{cccccccc}
\hline \hline Period & BAMA & Who & MAJAMIROTE & PALIGABA & PENDIREKOR & SAND \\
\hline \hline & 0.000000 & 0.000000 & 0.464070 & 0.061744 & 0.164601 & 0.043006 \\
1 & 0.413037 & 0.004112 & 0.134324 & 0.097540 & -0.052935 & 0.066039 & 0.110917 \\
2 & 0.203681 & -0.006626 & 0.023296 & 0.062691 & 0.043641 & 0.022888 & 0.134171 \\
3 & 0.063207 & -0.003450 & 0.003808 & 0.022690 & 0.027542 & 0.006585 \\
4 & 0.016580 & -0.002273 & -0.000128 & 0.006810 & 0.012317 & 0.001558 \\
5 & 0.003691 & -0.000953 & -0.000365 & 0.001733 & 0.004399 & 0.000238 \\
6 & 0.000653 & -0.000328 & -0.000187 & 0.000371 & 0.001365 & $-9.99 \mathrm{E}-07$ & 0.00620279 \\
7 & $5.46 \mathrm{E}-05$ & $-9.93 \mathrm{E}-05$ & $-7.20 \mathrm{E}-05$ & $5.92 \mathrm{E}-05$ & 0.000379 & $-1.94 \mathrm{E}-05$ & 0.001729 \\
8 & $-2.41 \mathrm{E}-05$ & $-2.69 \mathrm{E}-05$ & $-2.39 \mathrm{E}-05$ & $1.65 \mathrm{E}-06$ & $9.38 \mathrm{E}-05$ & $-1.03 \mathrm{E}-05$ \\
9 & $-1.78 \mathrm{E}-05$ & $-6.43 \mathrm{E}-06$ & $-7.10 \mathrm{E}-06$ & $-4.02 \mathrm{E}-06$ & $1.98 \mathrm{E}-05$ & $-3.98 \mathrm{E}-06$ \\
10 & & & & & $8.79 \mathrm{E}-05$ \\
\hline \hline
\end{tabular}

Source: Data processing results, 2020.

This result is also in accordance with the previous analysis, in which the price movements of the processed food group, beverages, cigarettes, and tobacco, in addition to not detaching from the price of groceries as part of the input, were also affected by the shock that occurred in the transportation, communication and financial services groups. Interesting findings from this result, sand group price shock gives a persistent influence where until the 6th month gives the effect of increasing prices on MAJAMIROTE group. In addition, the shock that occurred in the BAMA, PALIGABA, SAND and TRASKOJA groups tended to result in a more persistent increase in MAJAMIROTE prices, compared to the shock impact of the other groups, which began to fall in the 9th and 10th months.

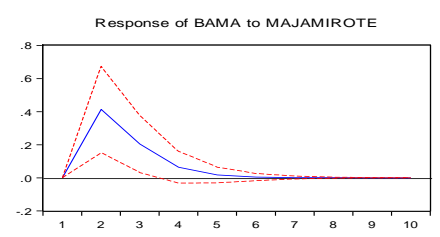

Response of PALIGABA to MAJAMIROTE

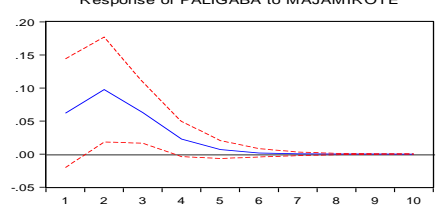

Response of TRASKOJA to MAJAMIROTE

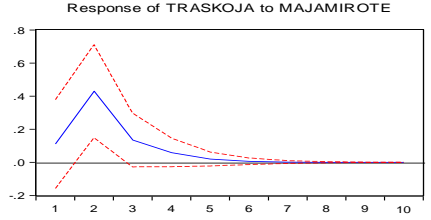

Source: Data processing results, 2020.
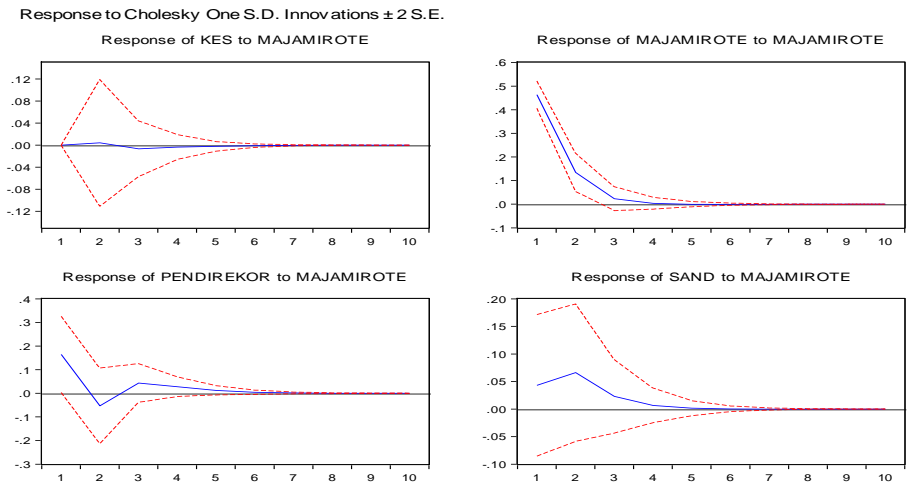

Figure 5. of MAJAMIROTE group IRF

\section{IRF Housing, Water, Electricity, Gas, and Fuel Group (PALIGABA)}

IRF results in PALIGABA group price in case of shock of 1 S.D. on each variable, in the 1st month ahead PALIGABA group price itself and TRASKOJA which caused the highest price increase compared to other groups, namely $0.47 \%$ and $0.19 \%$. However, the shock in TRASKOJA group decreased in the 10th month. While in the PALIGABA group itself persisted with a fairly high shock up to the 8 th month of $0.47 \%$ to $0.0000024 \%$. 
Table 7. IRF PALIGABA Group

\begin{tabular}{|c|c|c|c|c|c|c|c|}
\hline Period & BAMA & Who & MAJAMIROTE & PALIGABA & PENDIREKOR & SAND & TRASKOJA \\
\hline 1 & 0.000000 & 0.000000 & 0.000000 & 0.468228 & -0.125971 & -0.018167 & 0.187334 \\
\hline 2 & 0.016480 & -0.012087 & 0.008389 & 0.045778 & 0.028919 & -0.051436 & 0.041230 \\
\hline 3 & 0.031069 & 0.001463 & 0.005826 & 0.008049 & 0.003631 & -0.008111 & 0.052695 \\
\hline 4 & 0.014490 & -0.000652 & 0.000328 & 0.004109 & 0.005674 & -0.000154 & 0.014868 \\
\hline 5 & 0.003759 & -0.000420 & -0.000215 & 0.001378 & 0.002796 & 0.000169 & 0.004635 \\
\hline 6 & 0.000678 & -0.000208 & -0.000143 & 0.000336 & 0.001011 & $3.04 \mathrm{E}-05$ & 0.001306 \\
\hline 7 & $5.74 \mathrm{E}-05$ & $-7.40 \mathrm{E}-05$ & $-5.74 \mathrm{E}-05$ & 5.67E-05 & 0.000299 & $-8.51 \mathrm{E}-06$ & 0.000325 \\
\hline 8 & $-2.01 \mathrm{E}-05$ & $-2.12 \mathrm{E}-05$ & $-1.89 \mathrm{E}-05$ & $2.40 \mathrm{E}-06$ & $7.47 \mathrm{E}-05$ & $-7.49 \mathrm{E}-06$ & $6.80 \mathrm{E}-05$ \\
\hline 9 & $-1.46 \mathrm{E}-05$ & $-5.14 \mathrm{E}-06$ & $-5.56 \mathrm{E}-06$ & $-3.17 \mathrm{E}-06$ & $1.56 \mathrm{E}-05$ & $-3.18 \mathrm{E}-06$ & $9.80 \mathrm{E}-06$ \\
\hline 10 & $-6.20 \mathrm{E}-06$ & $-1.01 \mathrm{E}-06$ & $-1.47 \mathrm{E}-06$ & $-1.87 \mathrm{E}-06$ & 2.32E-06 & $-1.06 \mathrm{E}-06$ & $-3.66 \mathrm{E}-07$ \\
\hline
\end{tabular}

Source: Data Processing Results, 2020

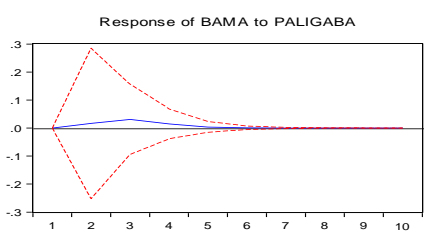

Response of PALIGABA to PALIGABA

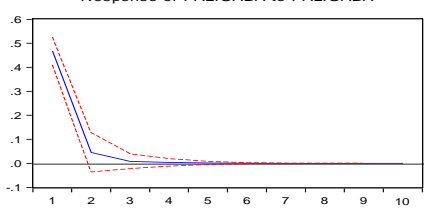

Response of TRASKOJA to PALIGABA

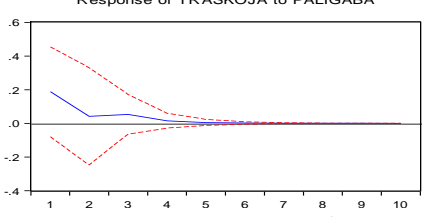

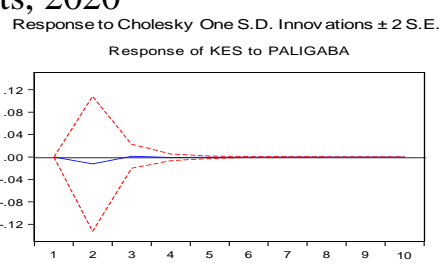

Response of PENDIREKOR to PALIGABA

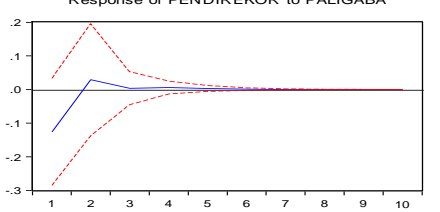

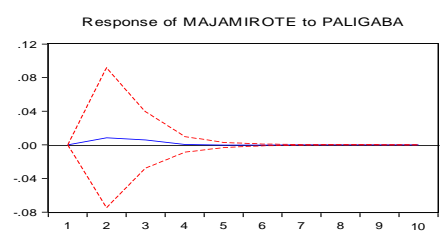

Response of SAND to PALIGABA

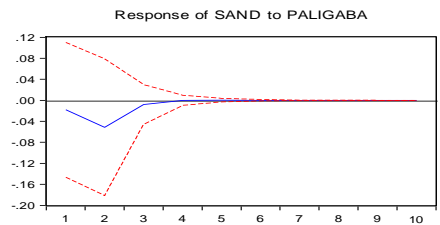

Source: Data processing results, 2020.

Figure 6. the PALIGABA Group IRF

PALIGABA group prices themselves also gave a shock price drop on itself in the 9th and 10th months. This is related to the nature of this commoditygroup whose pricing is heavily influenced by administered prices, especially in sub-groups of fuel, lighting, and water. In addition, in the subgroup of housing costs will also persistently, especially the nature of either land or houses widely used as a means of investment. The impact of the persistence of PALIGABA group price increase also occurred due to the shock of BAMA, PENDIREKOR and TRASKOJA MAJADI group, which showed the impact on PALIGABA price movement closer to the balance price.

\section{IRF Education, Recreation and Sports Group (PENDIREKOR)}

The positive shock of 1 S.D. in the first month of each variable which led to the highest price increase in the PENDIREKOR group price was the PENDIREKOR group itself by $0.91 \%$, the range below $1 \%$ continued until the 4th month after which there was a decrease in the price until the end of the period. The biggest increase also came from a shock in sand group prices as in the first month of $0.16 \%$. TRASKOJA group prices led to price declines for most of the period except the 2nd and 4th months. This is of course related to the cost of operational needs in this PENDIREKOR group towards subgroups of fuel, lighting, and water. In addition, sand group prices resulted in price increases except in the 4th and 5th months, where the needs of education and sports were not separated from the needs in the group, especially that supported the needs related to the implementation of education such as school uniforms in line with the pattern of starting the educational schedule that began at the beginning of the year. 
Table 8. IRF PENDIREKOR Group

\begin{tabular}{cccccccc}
\hline \hline Period & BAMA & Who & MAJAMIROTE & PALIGABA & PENDIREKOR & SAND & TRASKOJA \\
\hline \hline 1 & 0.000000 & 0.000000 & 0.000000 & 0.000000 & 0.905263 & 0.162976 \\
2 & -0.092866 & -0.035523 & 0.003388 & -0.011091 & 0.086606 & 0.057791 & 0.177737 \\
3 & -0.024210 & -0.015132 & -0.005238 & -0.002270 & 0.025579 & 0.003982 & -0.012036 \\
4 & -0.006719 & -0.001184 & $-8.08 \mathrm{E}-05$ & -0.002003 & 0.001205 & -0.000645 & 0.000131 \\
5 & -0.001008 & -0.000102 & $2.65 \mathrm{E}-05$ & -0.000489 & -0.000320 & -0.000154 & -0.000439 \\
6 & -0.000109 & $2.52 \mathrm{E}-05$ & $1.90 \mathrm{E}-05$ & $-8.74 \mathrm{E}-05$ & -0.000160 & $-1.88 \mathrm{E}-05$ & -0.000185 \\
7 & $-5.70 \mathrm{E}-06$ & $1.26 \mathrm{E}-05$ & $7.19 \mathrm{E}-06$ & $-1.20 \mathrm{E}-05$ & $-4.73 \mathrm{E}-05$ & $1.56 \mathrm{E}-06$ & $-5.17 \mathrm{E}-05$ \\
8 & $1.72 \mathrm{E}-06$ & $3.42 \mathrm{E}-06$ & $2.27 \mathrm{E}-06$ & $-9.12 \mathrm{E}-07$ & $-1.15 \mathrm{E}-05$ & $1.41 \mathrm{E}-06$ & $-1.26 \mathrm{E}-05$ \\
9 & $1.18 \mathrm{E}-06$ & $8.05 \mathrm{E}-07$ & $7.07 \mathrm{E}-07$ & $2.00 \mathrm{E}-07$ & $-2.57 \mathrm{E}-06$ & $4.72 \mathrm{E}-07$ \\
10 & $5.74 \mathrm{E}-07$ & $1.72 \mathrm{E}-07$ & $2.07 \mathrm{E}-07$ & $1.64 \mathrm{E}-07$ & $-5.05 \mathrm{E}-07$ & $1.38 \mathrm{E}-07$ \\
\hline \hline
\end{tabular}

Source: Data Processing Results, 2020

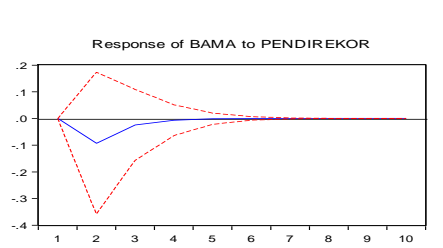

Response of PALIGABA to PENDIREKOF

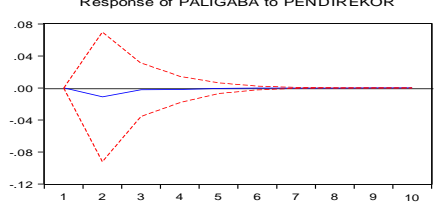

Response of TRASKOJA to PENDIREKO

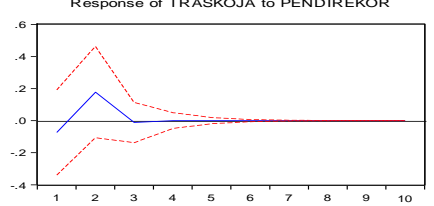

Source: Data processing results, 2020.

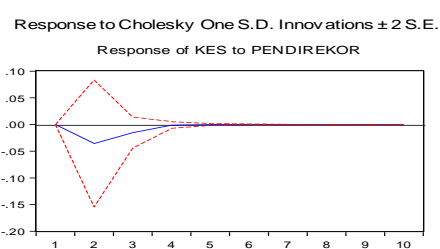

Response of PENDIREKOR to PENDIREKOR

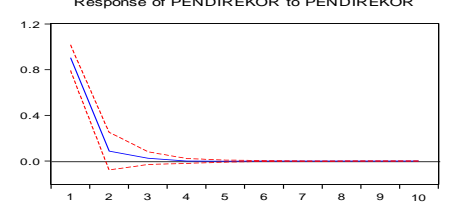

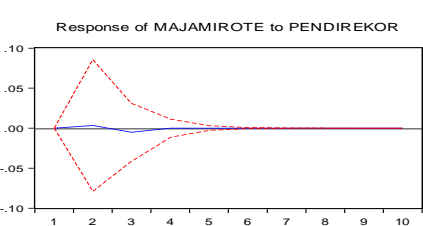

Response of SAND to PENDIREKOR

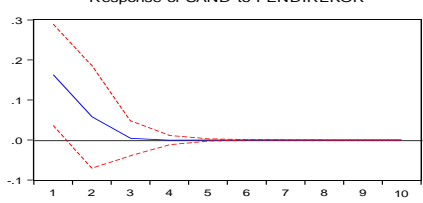

Figure 7. the IRF PENDIREKOR Group

\section{IRF Sandang Group (SAND)}

In the event of a positive shock of 1 S.D. in each commodity group price, in the first month ahead, the price of BAMA, KES, MAJAMIROTE, PALIGABA and PENDIREKOR group does not have any impact. The highest price increase in the first month occurred when there was a shock from the SAND group itself by $0.72 \%$. There was a drop in prices in the 2nd to 7th month when there was shock from BAMA group, KES, MAJAMIROTE, PALIGABA, PENDIREKOR, SAND and TRASKOJA. The shock in BAMA, KES, MAJAMIROTE and SAND groups itself also led to an increase in sand group price almost in each period with a fairly small proportion of under $1 \%$. The most common price drop occurs when there is shock in PALIGABA, PENDIREKOR and TRASKOJA groups with an average duration of 4-6 months. This indicates that the shock that occurred in other commodity groups also turned out to impact sand group prices. Various shocks from commodity group prices to sand group prices have led to persistent increases in prices in this group over the next 10 months, except in the PENDIREKOR and TRASKOJA groups.

Table 9. IRF Group SAND

\begin{tabular}{|c|c|c|c|c|c|c|c|}
\hline Period & BAMA & Who & MAJAMIROTE & PALIGABA & PENDIREKOR & SAND & TRASKOJA \\
\hline 1 & 0.000000 & 0.000000 & 0.000000 & 0.000000 & 0.000000 & 0.715761 & -0.234224 \\
\hline 2 & -0.214539 & -0.046577 & -0.022896 & -0.008058 & 0.039814 & 0.080814 & -0.360186 \\
\hline
\end{tabular}




\begin{tabular}{cccccccc}
3 & -0.079059 & 0.000576 & 0.006282 & -0.019056 & -0.031622 & 0.002065 & -0.067528 \\
4 & -0.012002 & 0.001972 & 0.003313 & -0.005258 & -0.015136 & -0.000415 & -0.018283 \\
5 & 0.000267 & 0.001071 & 0.001228 & -0.000647 & -0.004644 & 0.000152 & -0.003975 \\
6 & 0.000923 & 0.000325 & 0.000366 & 0.000131 & -0.001049 & 0.000162 & -0.000577 \\
7 & 0.000419 & $6.93 \mathrm{E}-05$ & $9.45 \mathrm{E}-05$ & 0.000116 & -0.000157 & $6.80 \mathrm{E}-05$ & $2.62 \mathrm{E}-05$ \\
8 & 0.000144 & $8.90 \mathrm{E}-06$ & $2.16 \mathrm{E}-05$ & $4.89 \mathrm{E}-05$ & $1.87 \mathrm{E}-06$ & $2.10 \mathrm{E}-05$ & $6.55 \mathrm{E}-05$ \\
9 & $4.38 \mathrm{E}-05$ & $-9.20 \mathrm{E}-07$ & $4.02 \mathrm{E}-06$ & $1.65 \mathrm{E}-05$ & $1.36 \mathrm{E}-05$ & $5.45 \mathrm{E}-06$ & $3.39 \mathrm{E}-05$ \\
10 & $1.21 \mathrm{E}-05$ & $-1.20 \mathrm{E}-06$ & $4.20 \mathrm{E}-07$ & $4.93 \mathrm{E}-06$ & $7.18 \mathrm{E}-06$ & $1.23 \mathrm{E}-06$ \\
\hline \hline
\end{tabular}

Source: Data Processing Results, 2020
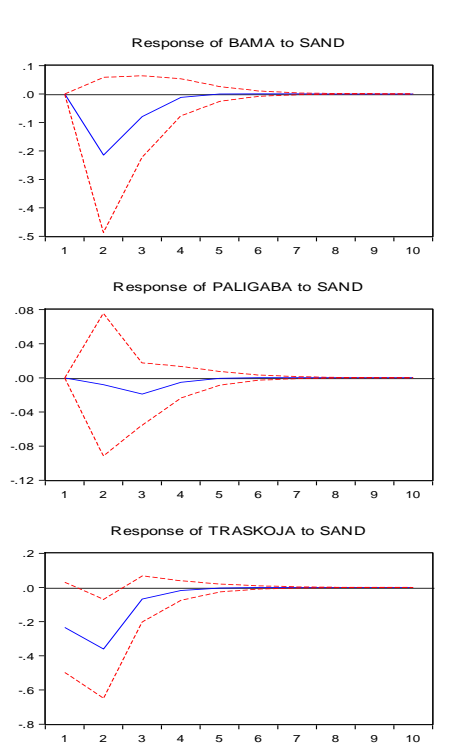

Source: Data processing results, 2020.
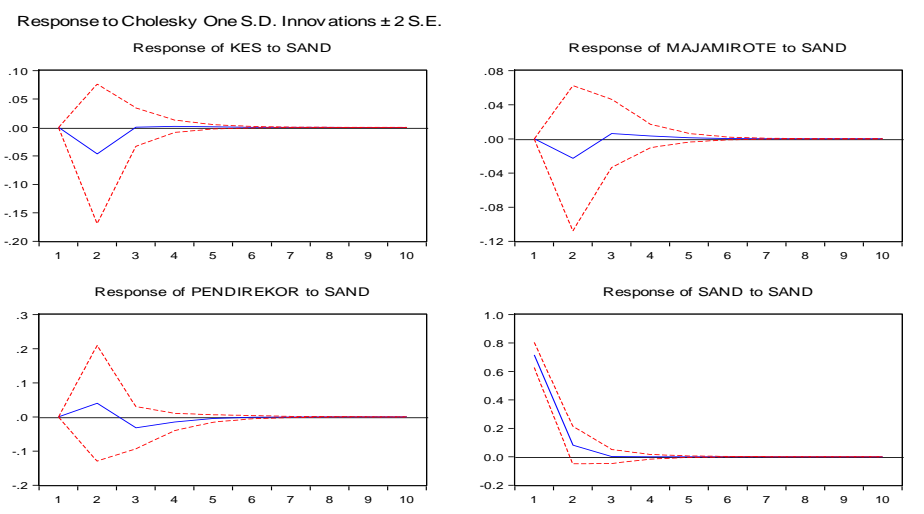

Figure 8. the SAND Group IRF

\section{IRF Group of Transportation, Communication and Financial Services (TRASKOJA)}

In the event of a positive shock of 1 S.D. in the first month ahead of each variable which causes the highest price increase in the price of the TRANS group is the TRANS group itself by $1.50 \%$, then PENDIREKOR in the 2 nd month by $0.15 \%$. The PALIGABA group's shock almost always leads to a decrease in prices throughout the period except in the 2nd month there is a price increase of $0.02 \%$. similar conditions are also found in the BAMA and SAND groups. The price influence of PALIGABA group especially from the fuel sub-group is relatively small on TRASKOJA group price, which provides shock with a range of less than $1 \%$. In addition, it was also found that the BAMA, PALIGABA, PENDIREKOR, SAND and TRASKOJA groups themselves almost always showed a decreased price response throughout the period. 
Table 10. IRF TRASKOJA Group

\begin{tabular}{cccccccc}
\hline \hline Period & BAMA & Who & MAJAMIROTE & PALIGABA & PENDIREKOR & SAND & TRASKOJA \\
\hline \hline 1 & 0.000000 & 0.000000 & 0.000000 & 0.000000 & 0.000000 & 0.000000 \\
2 & 0.006973 & -0.056109 & -0.055313 & 0.017454 & 0.152578 & -0.017012 & -0.019670 \\
3 & -0.029267 & -0.004059 & -0.009056 & -0.007080 & 0.021521 & -0.007488 & 0.020048 \\
4 & -0.012250 & -0.001648 & -0.002842 & -0.003690 & 0.003275 & -0.001914 & -0.002537 \\
5 & -0.004406 & -0.000162 & -0.000639 & -0.001503 & -0.000345 & -0.000599 & -0.002489 \\
6 & -0.001365 & $5.11 \mathrm{E}-05$ & -0.000111 & -0.000512 & -0.000491 & -0.000158 \\
7 & -0.000375 & $4.17 \mathrm{E}-05$ & $-8.45 \mathrm{E}-06$ & -0.000153 & -0.000240 & $-3.60 \mathrm{E}-05$ & -0.001140 \\
8 & $-9.17 \mathrm{E}-05$ & $1.89 \mathrm{E}-05$ & $4.78 \mathrm{E}-06$ & $-4.07 \mathrm{E}-05$ & $-9.06 \mathrm{E}-05$ & $-6.46 \mathrm{E}-06$ & -0.000138 \\
9 & $-1.89 \mathrm{E}-05$ & $6.85 \mathrm{E}-06$ & $3.33 \mathrm{E}-06$ & $-9.54 \mathrm{E}-06$ & $-2.96 \mathrm{E}-05$ & $-5.23 \mathrm{E}-07$ & $-3.99 \mathrm{E}-05$ \\
10 & $-2.69 \mathrm{E}-06$ & $2.18 \mathrm{E}-06$ & $1.43 \mathrm{E}-06$ & $-1.82 \mathrm{E}-06$ & $-8.67 \mathrm{E}-06$ & $2.52 \mathrm{E}-07$ \\
\hline \hline
\end{tabular}

Source: Data Processing Results, 2020
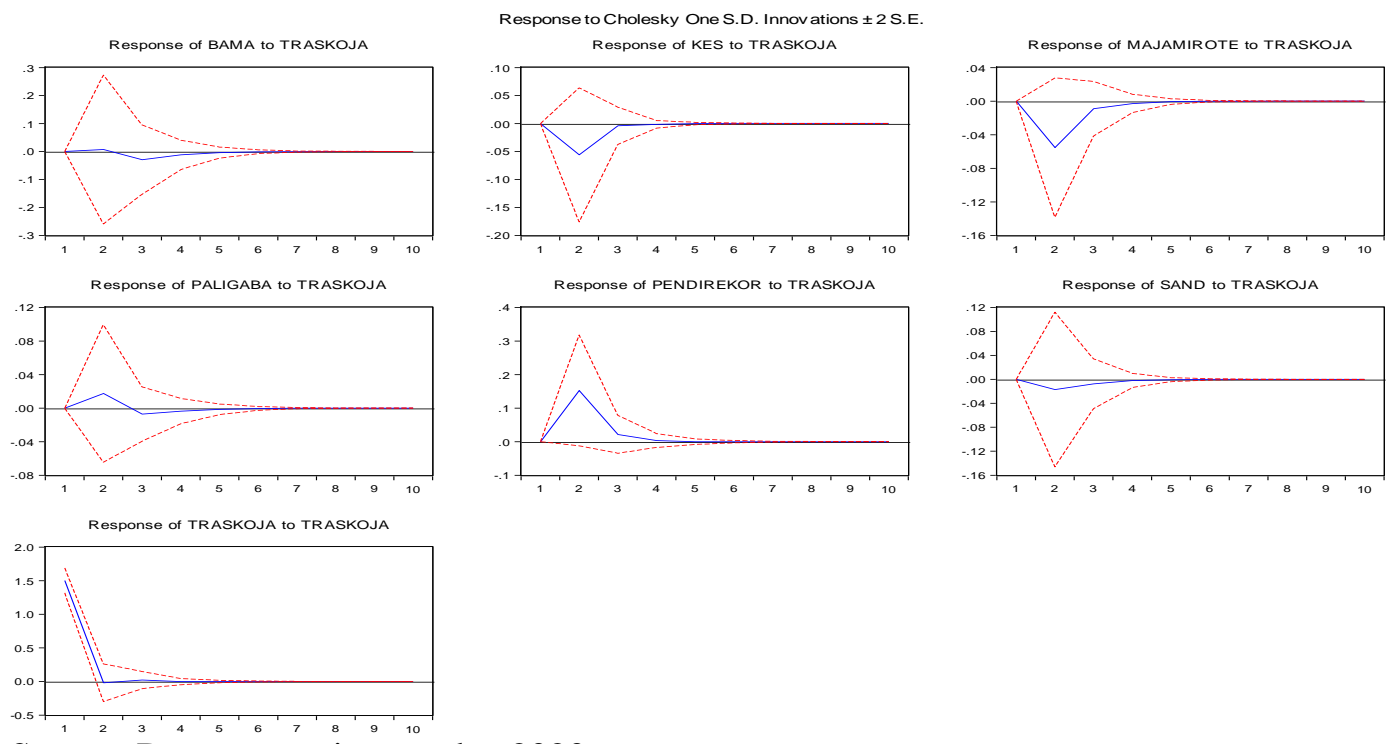

Source: Data processing results, 2020.

Figure 9. TRASKOJA Group IRF

\section{VD Grocery Group (BAMA)}

Based on the table below, the contribution of each endogenous variable shock to the price fluctuations of the BAMA group. Data in the first month showed the increase in BAMA group prices was more due to the BAMA group's price $(100 \%)$. So many factors causing the increase in prices in the BAMA group are of its own, this confirms that factors of structural and geographical nature such as seasons, weather, to crop failures in sub-subgroups within which consist largely of production in primary sectors such as agriculture are very dominant affecting price fluctuations. Entering the 5th month until the end of the shock contribution period remains at $88.73 \%$.

Table 11. VD BAMA Group

\begin{tabular}{|c|c|c|c|c|c|c|c|c|}
\hline \multirow[b]{2}{*}{ Period } & \multicolumn{8}{|c|}{ Variance Decomposition of BAMA: } \\
\hline & S.E. & BAMA & Who & MAJAMIROTE & PALIGABA & PENDIREKOR & SAND & TRASKOJA \\
\hline 1 & 1.536585 & 100.0000 & 0.000000 & 0.000000 & 0.000000 & 0.000000 & 0.000000 & 0.000000 \\
\hline 2 & 1.654641 & 90.66096 & 1.100028 & 6.231183 & 0.009920 & 0.314994 & 1.681139 & 0.001776 \\
\hline 3 & 1.671495 & 88.89323 & 1.238288 & 7.591038 & 0.044271 & 0.329652 & 1.871120 & 0.032399 \\
\hline 4 & 1.672968 & 88.73713 & 1.249389 & 7.720423 & 0.051695 & 0.330685 & 1.872974 & 0.037703 \\
\hline
\end{tabular}




\begin{tabular}{|ccccccccc|}
\hline 5 & 1.673067 & 88.72698 & 1.249666 & 7.729331 & 0.052194 & 0.330682 & 1.872756 & 0.038392 \\
6 & 1.673072 & 88.72645 & 1.249663 & 7.729768 & 0.052210 & 0.330680 & 1.872774 & 0.038458 \\
7 & 1.673072 & 88.72642 & 1.249663 & 7.729780 & 0.052210 & 0.330680 & 1.872779 & 0.038463 \\
8 & 1.673072 & 88.72642 & 1.249663 & 7.729780 & 0.052210 & 0.330680 & 1.872780 & 0.038463 \\
9 & 1.673072 & 88.72642 & 1.249663 & 7.729780 & 0.052210 & 0.330680 & 1.872780 & 0.038463 \\
10 & 1.673072 & 88.72642 & 1.249663 & 7.729780 & 0.052210 & 0.330680 & 1.872780 & 0.038463 \\
\hline
\end{tabular}

Source: Data Processing Results, 2020

The price fluctuations of this BAMA group in addition to being influenced by itself are also influenced by MAJAMIROTE group price with a contribution of 6-7\%. Meanwhile, kes and SAND groups contributed shock above $1 \%$. TRASKOJA Group also contributed a shock of 0.039 from the $3 \mathrm{rd}$ month to the end of the period. The group has an entry role in the cost structure to distribute supplies from farmers producers directly to collector traders to retail traders. This shock contribution composition is still the same until the end of the period in which BAMA group amounted to $88.73 \%$, MAJAMIROTE group by 7,735 , KES group by $1.25 \%$, SAND group by $1.87 \%$, and another group less than $1 \%$. The largest price fluctuation shock contribution is spread across three groups: BAMA group itself, MAJAMIROTE and SAND. The PALIGABA group is included in the second smallest contribution, one of which comes from the fuel sub-group, which is also part of the input cost in transportation for BAMA group distribution.

\section{VD Group Health (KES)}

Based on the results in the first month ahead, the largest contribution to price changes in the KES group is its own variable of $99.96 \%$. The other groups that contributed the biggest shock fluctuations after the KES group were TRASKOJA group by $0.65 \%$ and SAND group by $0.45 \%$. This condition lasts throughout the period, where in the 7th to 10th month, the shock contribution size tends to remain. Other groups other than the KES group themselves contribute shock relatively small price fluctuations of less than $1 \%$.

Table 12. VD KES GROUP

\begin{tabular}{|cccccccccc|}
\hline \multirow{2}{*}{ Period } & S.E. & BAMA & Who & Mariance Decomposition of KES: \\
& & & & & & \\
& & & & & & & \\
1 & & 0.690973 & 0.041843 & 99.95816 & 0.000000 & 0.000000 & 0.000000 & 0.000000 & 0.000000 \\
2 & 0.695955 & 0.070987 & 98.53693 & 0.003490 & 0.030164 & 0.260532 & 0.447903 & 0.649992 \\
3 & 0.696287 & 0.085040 & 98.46401 & 0.012542 & 0.030577 & 0.307516 & 0.447544 & 0.652770 \\
4 & 0.696315 & 0.088872 & 98.45610 & 0.014996 & 0.030662 & 0.307780 & 0.448309 & 0.653276 \\
5 & 0.696321 & 0.089139 & 98.45452 & 0.016061 & 0.030698 & 0.307777 & 0.448538 & 0.653270 \\
6 & 0.696322 & 0.089149 & 98.45429 & 0.016248 & 0.030707 & 0.307776 & 0.448559 & 0.653269 \\
7 & 0.696322 & 0.089149 & 98.45427 & 0.016270 & 0.030708 & 0.307776 & 0.448560 & 0.653270 \\
8 & 0.696322 & 0.089149 & 98.45426 & 0.016272 & 0.030708 & 0.307776 & 0.448560 & 0.653270 \\
9 & 0.696322 & 0.089149 & 98.45426 & 0.016272 & 0.030708 & 0.307776 & 0.448560 & 0.653270 \\
10 & 0.696322 & 0.089149 & 98.45426 & 0.016272 & 0.030708 & 0.307776 & 0.448560 & 0.653270 \\
\hline
\end{tabular}

Source: Data Processing Results, 2020

The IRF results also show that the KES group variable's shock effect leads to persistent price increases over the next 10 months. This suggests that the variable role itself needs to be considered if it is to control inflation in this group. Similarly, TRASKOJA and sand groups gradually cause the price increase of KES group by increasingly avoiding the price of balance.

\section{VD Group of Processed food, Beverages, Cigarettes and Tobacco (MAJAMIROTE)}

The table below shows that the shock contribution to MAJAMIROTE group prices in the first month was dominated by its own variables $(94.37 \%)$, followed by kes group price $(5.43 \%)$. BAMA group accounted for $0.20 \%$. This indicates that MAJAMIROTE group production has a reliance on inputs derived from BAMA group, so the increase in prices in BAMA group contributes quite a small amount to the increase in prices in MAJAMIROTE group in the first month ahead. Starting from the 5th month MAJAMIROTE group contribution itself tends to remain until the end of the period of $93.11 \%$ in line with the community's adjustments, especially with the selection of certain substitution 
goods to respond to the price increase on an item in this group. BAMA, PALIGABA, PENDIREKOR and SAND groups contributed relatively small shock contributions to the MAJAMIROTE group below 1\%. Meanwhile, the contribution of TRASKOJA group price is increasing and from the 6th month until the end of the period remains at $1.25 \%$ related to the distribution and marketing that continues to be done in MAJAMIROTE group so that the price contribution to TRASKOJA group is increasingly greater.

Table 13. VD MAJAMIROTE Group

\begin{tabular}{|c|c|c|c|c|c|c|c|c|}
\hline \multicolumn{9}{|c|}{ Variance Decomposition of MAJAMIROTE: } \\
\hline Period & S.E. & BAMA & Who & MAJAMIROTE & PALIGABA & PENDIREKOR & SAND & TRASKOJA \\
\hline 1 & 0.477719 & 0.202520 & 5.429882 & 94.36760 & 0.000000 & 0.000000 & 0.000000 & 0.000000 \\
\hline 2 & 0.500340 & 0.296493 & 5.004445 & 93.23483 & 0.028113 & 0.004585 & 0.209401 & 1.222136 \\
\hline 3 & 0.501231 & 0.336293 & 5.012057 & 93.11983 & 0.041526 & 0.015489 & 0.224367 & 1.250440 \\
\hline 4 & 0.501277 & 0.341364 & 5.011252 & 93.10822 & 0.041561 & 0.015489 & 0.228693 & 1.253420 \\
\hline 5 & 0.501281 & 0.341739 & 5.011268 & 93.10707 & 0.041579 & 0.015489 & 0.229290 & 1.253567 \\
\hline 6 & 0.501281 & 0.341762 & 5.011275 & 93.10697 & 0.041587 & 0.015489 & 0.229343 & 1.253570 \\
\hline 7 & 0.501281 & 0.341763 & 5.011276 & 93.10697 & 0.041588 & 0.015489 & 0.229346 & 1.253570 \\
\hline 8 & 0.501281 & 0.341763 & 5.011276 & 93.10697 & 0.041588 & 0.015489 & 0.229346 & 1.253570 \\
\hline 9 & 0.501281 & 0.341763 & 5.011276 & 93.10697 & 0.041588 & 0.015489 & 0.229346 & 1.253570 \\
\hline 10 & 0.501281 & 0.341763 & 5.011276 & 93.10697 & 0.041588 & 0.015489 & 0.229346 & 1.253570 \\
\hline
\end{tabular}

Source: Data Processing Results, 2020

\section{VD Housing Group, Water, Electricity, Gas, and Fuel (PALIGABA)}

The results show that the shock contribution to PALIGABA group price fluctuations is dominated by the variable itself, where it has a contribution from the 1st month to the next 10 months with contributions in the range of $88.28-98.14 \%$. Entering the 8th month its contribution remained until the end of the period at $88.28 \%$. the largest PALIGABA group price fluctuation shock contribution is spread into the other two groups, namely the MAJAMIROTE group in the 10th month, which accounted for $7.11 \%$ and BAMA group by $3.86 \%$. This phenomenon shows that in PALIGABA group price shapers where there are sub-groups whose prices are based on administered prices then price adjustment after shock will depend heavily on the government's own policies. That is the decision to lower prices on sub-groups that are included in administered prices, especially in sub-groups of fuel, lighting, and water. In addition, vd analysis shows that TRASKOJA group's role in influencing price movements in PALIGABA group is not very large, below $1 \%$. The government's policy of simultaneously increasing prices in these two groups is the hardest condition that society has to face in maintaining its purchasing power. Thus, although the economic value of PALIGABA group input costs has increased, the government is likely to withstand the price increase, especially if strategic considerations do not allow to increase the price at that time.

Table 14. VD PALIGABA Group

\begin{tabular}{|ccccccccc|}
\hline \multirow{2}{*}{ Period } & S.E. & BAMA & Who & MAJAMIROTE & PALIGABA & PENDIREKOR & SAND & TRASKOJA \\
& & & & & & & & \\
1 & 0.472652 & 0.056004 & 0.100710 & 1.706482 & 98.13680 & 0.000000 & 0.000000 & 0.000000 \\
2 & 0.494964 & 3.720741 & 0.294780 & 5.439572 & 90.34384 & 0.050211 & 0.026507 & 0.124349 \\
3 & 0.500134 & 3.864962 & 0.360204 & 6.898909 & 88.51171 & 0.051237 & 0.171142 & 0.141832 \\
4 & 0.500761 & 3.858087 & 0.376804 & 7.086947 & 88.29681 & 0.052708 & 0.181737 & 0.146908 \\
5 & 0.500815 & 3.857314 & 0.377829 & 7.103906 & 88.27852 & 0.052792 & 0.181865 & 0.147777 \\
6 & 0.500819 & 3.857301 & 0.377861 & 7.105001 & 88.27729 & 0.052794 & 0.181869 & 0.147879 \\
7 & 0.500819 & 3.857305 & 0.377862 & 7.105051 & 88.27723 & 0.052795 & 0.181874 & 0.147888 \\
8 & 0.500819 & 3.857305 & 0.377862 & 7.105052 & 88.27722 & 0.052795 & 0.181875 & 0.147889 \\
9 & 0.500819 & 3.857305 & 0.377862 & 7.105052 & 88.27722 & 0.052795 & 0.181875 & 0.147889 \\
10 & 0.500819 & 3.857305 & 0.377862 & 7.105052 & 88.27722 & 0.052795 & 0.181875 & 0.147889 \\
\hline
\end{tabular}

Source: Data Processing Results, 2020. 


\section{VD Education, Recreation and Sports Group (PENDIREKOR)}

The results also confirmed an analysis of IRF results in which in the 1st month the largest contribution of gejolak price contributors to the PENDIREKOR group was variable itself at $91.28 \%$. In addition, a considerable contribution came from MAJAMIROTE group of $3.02 \%$ and KES by $3.50 \%$. The group that contributed the smallest was SAND less than $1 \%$. The implementation of many educational operations also requires input from other commodity groups such as BAMA and TRASKOJA.

Table 15. VD PENDIREKOR Group

\begin{tabular}{|ccccccccc|}
\hline \multicolumn{1}{c}{ Period } & S.E. & BAMA & Who & MAJAMIROTE & PALIGABA & PENDIREKOR & SAND & TRASKOJA \\
& & & & & & & & \\
1 & 0.947013 & 0.330464 & 3.501968 & 3.021016 & 1.769413 & 91.37714 & 0.000000 & 0.000000 \\
2 & 0.973739 & 1.920588 & 3.321255 & 3.152984 & 1.761820 & 87.22090 & 0.167184 & 2.455266 \\
3 & 0.977417 & 2.234744 & 3.296570 & 3.328654 & 1.749965 & 86.63417 & 0.270598 & 2.485300 \\
4 & 0.978122 & 2.258454 & 3.300983 & 3.403150 & 1.750810 & 86.50961 & 0.294154 & 2.482843 \\
5 & 0.978228 & 2.259102 & 3.301821 & 3.418266 & 1.751249 & 86.49090 & 0.296345 & 2.482318 \\
6 & 0.978240 & 2.259070 & 3.301892 & 3.420204 & 1.751313 & 86.48879 & 0.296452 & 2.482283 \\
7 & 0.978241 & 2.259065 & 3.301895 & 3.420392 & 1.751318 & 86.48859 & 0.296454 & 2.482283 \\
8 & 0.978241 & 2.259065 & 3.301895 & 3.420406 & 1.751318 & 86.48858 & 0.296454 & 2.482284 \\
9 & 0.978241 & 2.259065 & 3.301895 & 3.420407 & 1.751318 & 86.48858 & 0.296454 & 2.482284 \\
10 & 0.978241 & 2.259065 & 3.301895 & 3.420407 & 1.751318 & 86.48858 & 0.296454 & 2.482284 \\
\hline
\end{tabular}

Source: Data Processing Results, 2020

\section{VD Sandang Group (SAND)}

The results show that the shock contribution to sand group price changes in the first month ahead was largely influenced by variabel itself of $92.08 \%$. However, in the 3rd month the role of the SAND variable itself was reduced to $89.24 \%$. in addition, influenced also by the PENDIREKOR group by $4.77 \%$ in the first month and BAMA group by $2.35 \%$. At the end of the 10th month, the biggest influence came from the SAND group itself $(89.23 \%)$, PENDIREKOR $(5.14 \%)$ and BAMA $(2.81 \%)$. This indicates that price fluctuations in the SAND group in the next few months in addition to being influenced by the group itself are also heavily influenced by the price of the PENDIREKOR and BAMA groups. Kes and MAJAMIROTE groups accounted for $1.07 \%$ and $1.17 \%$ in the 10th month. The other two groups, PALIGABA and TRASKOJA, contributed less than $1 \%$.

\section{Table 16. VD SAND GROUP}

\begin{tabular}{|ccccccccc|}
\hline \multirow{2}{*}{ Period } & S.E. & BAMA & Who & MAJAMIROTE & PALIGABA & PENDIREKOR & SAND & TRASKOJA \\
& & & & & & & & \\
1 & 0.745895 & 2.349259 & 0.401573 & 0.332428 & 0.059324 & 4.774123 & 92.08329 & 0.000000 \\
2 & 0.761980 & 2.789696 & 1.066860 & 1.069662 & 0.512517 & 5.149910 & 89.36151 & 0.049843 \\
3 & 0.762499 & 2.807461 & 1.065448 & 1.158308 & 0.523134 & 5.145627 & 89.24060 & 0.059418 \\
4 & 0.762533 & 2.807230 & 1.065918 & 1.165664 & 0.523092 & 5.145247 & 89.23281 & 0.060043 \\
5 & 0.762535 & 2.807259 & 1.065930 & 1.166075 & 0.523094 & 5.145223 & 89.23231 & 0.060105 \\
6 & 0.762535 & 2.807266 & 1.065930 & 1.166084 & 0.523094 & 5.145222 & 89.23230 & 0.060109 \\
7 & 0.762535 & 2.807267 & 1.065930 & 1.166084 & 0.523094 & 5.145221 & 89.23229 & 0.060109 \\
8 & 0.762535 & 2.807267 & 1.065930 & 1.166084 & 0.523094 & 5.145221 & 89.23229 & 0.060109 \\
9 & 0.762535 & 2.807267 & 1.065930 & 1.166084 & 0.523094 & 5.145221 & 89.23229 & 0.060109 \\
10 & 0.762535 & 2.807267 & 1.065930 & 1.166084 & 0.523094 & 5.145221 & 89.23229 & 0.060109 \\
\hline
\end{tabular}

Source: Data processing results, 2020.

\section{VD Group of Transportation, Communication and Financial Services (TRASKOJA)}

The results confirm IRF results where the composition of contributors per price change in the second largest TRASKOJA group is BAMA group (9.79\%) and SAND (2.09\%) at the beginning of the period. However, entering the month MAJAMIROTE group became the third contributor to the targeted $6.57 \%$ which lasted until the end of the period. TRASKOJA group itself as the largest contributor until the 10th month contributed $74.33 \%$. The KES group is the smallest contributor with 
a proportion of less than $1 \%$. While the other groups namely PALIGABA and PENDIREKOR until the end of consecutive periods accounted for 1,315 and $1.22 \%$.

Table 17. VD TRASKOJA Group

\begin{tabular}{|ccccccccccc}
\hline \multirow{2}{*}{ Period } & S.E. & BAMA & Who & MAJAMIROTE & PALIGABA & PENDIREKOR & SAND & TRASKOJA \\
& & & & & & & & \\
1 & 1.619324 & 9.786507 & 0.023153 & 0.469169 & 1.338336 & 0.206480 & 2.092154 & 86.08420 \\
2 & 1.731744 & 9.464233 & 0.062521 & 6.573978 & 1.226897 & 1.233927 & 6.155331 & 75.28311 \\
3 & 1.741516 & 9.450307 & 0.235339 & 7.093975 & 1.304722 & 1.224896 & 6.236809 & 74.45395 \\
4 & 1.742792 & 9.440958 & 0.242776 & 7.199286 & 1.310090 & 1.223102 & 6.238679 & 74.34511 \\
5 & 1.742931 & 9.439589 & 0.243585 & 7.211674 & 1.310588 & 1.222913 & 6.238203 & 74.33345 \\
6 & 1.742944 & 9.439452 & 0.243644 & 7.212850 & 1.310625 & 1.222897 & 6.238123 & 74.33241 \\
7 & 1.742945 & 9.439442 & 0.243647 & 7.212940 & 1.310627 & 1.222895 & 6.238117 & 74.33233 \\
8 & 1.742945 & 9.439441 & 0.243647 & 7.212946 & 1.310627 & 1.222895 & 6.238116 & 74.33233 \\
9 & 1.742945 & 9.439441 & 0.243647 & 7.212946 & 1.310627 & 1.222895 & 6.238116 & 74.33233 \\
10 & 1.742945 & 9.439441 & 0.243647 & 7.212946 & 1.310627 & 1.222895 & 6.238116 & 74.33233 \\
\hline
\end{tabular}

Source: Data Processing Results, 2020

\section{Conclusions}

Based on the results of data analysis, this study provides several conclusions as follows:

a. The inflation rate in one group of goods/services commodities in Banten is proven to have a dynamic relationship and effect on other goods/services commodity groups' inflation rate.

b. The group itself dominates the inflation movement of each commodity group of goods/services.

Meanwhile the policies implications are bellow.

a. Controlling inflation in the region is not enough just through monetary policy on a national scale. In many areas, the problem of inflation is non-monetary or needs good coordination with the Local Government regarding its control. Therefore, in addition to relying on economic policy nationally, it is also necessary for the policies of local governments in controlling inflation in the region, so that the role and function of the Regional Inflation Control Team (TPID) that has been established becomes very important and crucial in formulating policies and recommendations related to the handling of regional inflation.

b. Inflation control in the region is partially controlled and focuses on a particular commodity group that is considered to make a major contribution in the shape of regional inflation, but should also look at the entire commodity group simultaneously. This is due to the interconnectedness between the price of inflation-forming commodity groups that contribute to the increase in inflation in other commodity groups.

\section{Limitation and study forward}

The linkages presented as the results are performed in commodity groups; thus, further research would inform more about inter-linkage between commodities.

\section{Acknowledgement}

University of Sultan Ageng Tirtayasa financially supports this research.

\section{References}

Azwar. (2016). Inflation in South Sulawesi Province: dynamic relationship analysis of commodity inflation of goods/services. Journal of the Financial Education and Training Agency of the Ministry of Finance of the Republic of Indonesia, 9(1), 47-66.

Bima, JJA. (2017). Analysis of inflation relationship between group of goods/services commodity in Central Java 2009.1-2015.12. Diponegoro University.

Boediono. (2014). Ekonomi Moneter (Edisi ketiga). Yogyakarta: BPFE.

[BPS] Central Bureau of Statistics of Banten. (2018). Consumer price index and inflation of Banten 2018. Central Bureau of Statistics of Banten.

[BPS] Central Bureau of Statistics of Banten. (2017). Consumer price index and inflation of Banten 2017. Central Bureau of Statistics of Banten. 
[BPS] Central Bureau of Statistics of Banten. (2016). Consumer price index and inflation of Banten 2016. Central Bureau of Statistics of Banten.

[BPS] Central Bureau of Statistics of Banten. (2015). Consumer price index and inflation of Banten 2015. Central Bureau of Statistics of Banten.

[BPS] Central Bureau of Statistics of Banten. (2014). Consumer price index and inflation of Banten 2014. Central Bureau of Statistics of Banten.

[BPS] Central Bureau of Statistics of Banten. (2013). Consumer price index and inflation of Banten 2013. Central Bureau of Statistics of Banten.

[BPS] Central Bureau of Statistics of Banten. (2012). Consumer price index and inflation of Banten 2012. Central Bureau of Statistics of Banten.

[BPS] Central Bureau of Statistics of Banten. (2011). Consumer price index and inflation of Banten 2011. Central Bureau of Statistics of Banten.

[BPS] Central Bureau of Statistics of Banten. (2010). Consumer price index and inflation of Banten 2010. Central Bureau of Statistics of Banten.

[BPS] Central Bureau of Statistics of Banten. (2009). Consumer Price Index and Inflation of Banten 2009. Central Bureau of Statistics of Banten.

[BPS] Central Bureau of Statistics of Banten. (2008). Consumer price index and inflation of Banten 2008. Central Bureau of Statistics of Banten.

Carlino, Gerald and Robert Defina. (1998). The differential regional effects of monetary policy. The Review of Economics and Statistics, 80(4), 572-587.

Clements, Kenneth W. and HY Izan. (1987) The measurement of inflation: a stochastic approach. Journal of Business and Economic Statistics, 5(3), 339-350.

Darman. (2013). Effect of economic growth on unemployment rate: analysis of okun law. Journal The Winners, 14(1), 1-12.

Dickey.DA and WAFuller., (1979). Distribution of estimators for autoregressive time series with a unit root. Journal of the American Statistical Association, 74, 427-443.

Gujarati, DN. \& Porter, DC. (2013). Basic Econometrics. Jakarta Salemba Empat.

Hartanto, Tri. 2011. Analisis keterkaitan harga antar kelompok komoditas pembentuk inflasi di Indonesia periode 2004-2010. Skripsi Thesis, Universitas Airlangga. Un-Published

Ichsandimas, M. \& Cahyadin, M. (2014). World oil prices and indonesia macroeconomic. Journal of Development Economics, 15(1), 27-33.

Mankiw, NG. (2019). Macroeconomics, 10th Edition. New York Macmillan International.

Phillips, AW. (1958). The relation between unemployment and the rate of change of money wage rates in the United Kingdom, 1861-1957. Ecnomica, 25(100), 283-299.

Pindyck, S., Robert and Daniel L, Rubinfeld. (1998). Economectrics Models and Economic Forecast, Fourth Edition. Singapore. McGraw Hill International Edition.

Ramadhan, Gaffari. (2009). Analisis keterkaitan harga antar kelompok komoditas pembentuk inflasi di Sumatera Barat. Buletin Ekonomi Moneter dan Perbankan, 11(3), 233-274.

Sims, Christopher A. (1980). Comparison of interwar and postwar business cycles: monetarism reconsidered. American Economic Review, 70(4), 250-257.

Stock, J.H. and Watson, M.W. (2005). Implications of dynamic factor models for VAR analysis. NBER working paper, No. W11467

Suharyadi. \& Purwanto, SK. (2013). Statistika untuk ekonomi dan keuangan modern. Jakarta. Salemba Empat.

Wimanda, Rizki E. (2006). Regional inflation in Indonesia: characteristic, convergence, and determinants. Bank Indonesia Working Paper, No.13. 